University of Michigan Law School University of Michigan Law School Scholarship Repository

2013

\title{
Congress Underestimated: The Case of the World Bank
}

Kristina Daugirdas

University of Michigan Law School, kdaugir@umich.edu

Available at: https://repository.law.umich.edu/articles/625

Follow this and additional works at: https://repository.law.umich.edu/articles

Part of the Constitutional Law Commons, Legislation Commons, Organizations Law Commons, and the President/Executive Department Commons

\section{Recommended Citation}

Daugirdas, Kristina. "Congress Underestimated: The Case of the World Bank." Am. J. Int'1 L. 107, no. 3 (2013): 517-62.

This Article is brought to you for free and open access by the Faculty Scholarship at University of Michigan Law School Scholarship Repository. It has been accepted for inclusion in Articles by an authorized administrator of University of Michigan Law School Scholarship Repository. For more information, please contact mlaw.repository@umich.edu. 
This article is reproduced with permission from the July 2013 issue of the American Journal of International Law $\odot 2013$ American Society of International Law. All rights reserved.

\title{
CONGRESS UNDERESTIMATED: THE CASE OF THE WORLD BANK
}

\author{
By Kristina Daugirdas*
}

International organizations undermine democracy, or so their critics charge: not only do international organizations themselves operate undemocratically, ${ }^{1}$ but they undercut democratic governance within their member states. In particular, when states participate in international organizations, they lose control over policy outcomes because each state must share decision-making authority with other member states. ${ }^{2}$ And within member states, national legislatures — the bodies specifically designed to be responsive to popular control—are marginalized. ${ }^{3}$ Legislatures lack direct influence over international organizations and also have little influence over the executive branch's interactions with such organizations. ${ }^{4}$

\footnotetext{
* Assistant Professor of Law, University of Michigan Law School. Many thanks to Tabatha Abu-El Haj, Sam Bagenstos, Nick Bagley, Michael Barr, Deb Burand, John Ciociari, Sherman Clark, Alicia Davis, David Fontana, Monica Hakimi, Daniel Halberstam, Scott Hershovitz, Don Herzog, Jim Krier, Nina Mendelson, Julian Mortenson, Richard Primus, Steve Ratner, Margo Schlanger, Paul Stephan, Ed Swaine, and the participants at the ASIL International Organizations and International Law in Domestic Courts workshops and the Wharton-Colorado University Junior International Law Scholars Workshop for helpful comments and conversations. My special appreciation to John Broderick for excellent research assistance, Seth Quidachay-Swan at the University of Michigan Law Library, and the individuals who agreed to be interviewed for this project.

${ }^{1}$ See, e.g., Jed Rubenfeld, Unilateralism and Constitutionalism, 79 N.Y.U. L. REV. 1971, 2017-18 (2004) (“The existing international governance organizations are famous for their undemocratic opacity, remoteness from popular or representative politics, elitism, and unaccountability. International governance institutions and their officers tend to be bureaucratic, diplomatic, technocratic - everything but democratic."); Eric Stein, International Integration and Democracy: No Love at First Sight, 95 AJIL 489, 491 (2001) (international organizations are "considered 'undemocratic' since they operate with little transparency or public and parliamentary scrutiny"); Detlev F. Vagts, International Agreements, the Senate, and the Constitution, 36 COLUM. J. TRANSNAT'L L. 143, 154 (1997).

2 See, e.g., Robert A. Dahl, Can International Organizations Be Democratic? A Skeptic's View, in DEMOCRACY'S EDGES 19, 22 (Ian Shapiro \& Casiano Hacker-Gordon eds., 1999); Karl Kaiser, Transnational Relations as a Threat to the Democratic Process, 25 INT'L ORG. 706, 714 (1971) ("As the number and activities of international organizations expand, an area grows in which major decisions are made without much democratic control by the peoples and institutions which are affected or which support these activities financially."); John O. McGinnis, Medellin and the Future of International Delegation, 118 YALE L.J. 1712, 1714 (2009). At the same time, states participating in international organizations gain traction on problems that would be difficult or impossible for them to address individually. See, e.g., Oona A. Hathaway, International Delegation and State Sovereignty, 71 Law \& CONTEMP. PROBS. 115 (2008); Robert O. Keohane, Stephen Macedo \& Andrew Moravcsik, Democracy-Enhancing Multilateralism, 63 INT'L ORG. 1, 4 (2009) ("This is the state of the current debate: critics of multilateralism point to the ways in which international institutions undermine democracy; defenders respond by stressing pragmatic benefits.").

${ }^{3}$ CURTIS A. BRADley, INTERNATIONAL LAW IN THE U.S. LEGAL SySTEM 100 (2013) (identifying concern that international organizations will empower the executive branch at the expense of the legislature); JOSÉ E. ALVAREZ, INTERNATIONAL ORGANIZATIONS AS LAW-MAKERS 396 (2005) (same); DAN SAROOSHI, INTERNATIONAL ORGANIZATIONS AND THEIR EXERCISE OF SOVEREIGN POWERS 15 (2005) (same).

${ }^{4}$ See, e.g., Stein, supra note 1, at 490 ("A new level of normative activity superimposed on national democratic systems makes citizen participation more remote, and parliamentary control over the executive, notoriously loose in foreign affairs matters, becomes even less effective.").
} 
Within the United States, this account reflects a familiar story about Congress's feeble participation in foreign affairs. Under the standard account, when it comes to foreign affairs, the executive branch is both well suited and highly motivated to take the initiative. ${ }^{5}$ By contrast, Congress is unmotivated and ineffective. ${ }^{6}$ At best, it is relegated to a reactive role. ${ }^{7}$ When questions arise concerning the proper allocation of constitutional authority between the president and Congress — as they often do in foreign affairs — the executive branch is in a good position to assert and defend the president's constitutional prerogatives. ${ }^{8}$ Congress is hobbled, however, by collective action problems as well as by the high transaction costs of responding both to the executive's unilateral actions and to the constitutional arguments made by the executive branch. ${ }^{9}$ Moreover, the longer that an international organization is around, the more profound the shift to the executive branch is thought to be: although the Senate (in the case of a treaty) or both houses of Congress (in the case of a congressionalexecutive agreement) initially authorize U.S. participation, the executive branch alone represents the United States once the organization is up and running. From that point on, the executive branch's actions are subject to little scrutiny by either Congress or the courts. ${ }^{10}$ The president may consequently find that international organizations provide an opportunity to pursue policies that Congress would affirmatively oppose-if only it had the opportunity to weigh in. ${ }^{11}$

Using the World Bank (Bank) as a case study, this article casts doubt on the empirical foundation for the claim that international organizations undermine democracy by undermining legislatures. The article also argues that the conventional wisdom about the executive branch's dominance in foreign affairs may be overstated-especially outside the context of wars and

${ }^{5}$ See, e.g., Terry M. Moe \& William G. Howell, The Presidential Power of Unilateral Action, 15 J. L. ECON. \& OrG. 132, 161-65 (1999); Harold HongJu KoH, The NATIONAL SECURITY CONSTITUTION (1990) (titling chapter 5 "Why the President Almost Always Wins in Foreign Affairs: Executive Initiative and Congressional Acquiescence").

${ }^{6}$ This perception of Congress has been forged largely through analyses of its performance during national security crises that may, or actually do, involve military action. See, e.g., KOH, supra note 5, at 117-33. Some commentators argued that presidential dominance, built up by wars and crises, has eroded Congress's ability to check executive dominance in foreign and domestic affairs alike. ERIC A. POSNER \& ADRIAN VERMEULE, THE EXECUTIVE UnbOUND (2010); BRUCE ACKERMAN, THE DECLINE AND FALl OF THE AMERICAN REPUBLIC (2010).

7 See, e.g., Daryl J. Levinson, Empire-Building, 118 HARV. L. REV. 915, 955-56 (2005); Paul B. Stephan, Accountability and International Lawmaking: Rules, Rents and Legitimacy, 17 NW. J. INT'L L. \& BUS. 681, 697-99 (1997).

${ }^{8}$ See Curtis A. Bradley \& Trevor W. Morrison, Historical Gloss and the Separation of Powers, 126 HARV. L. REV. 411 (2012).

9 See Moe \& Howell, supra note 5, at 144-46; Bradley \& Morrison, supra note 8, at 438-44; Julian Davis Mortenson, Executive Power and the Discipline of History, 78 U. CHI. L. REV. 377, 412-16 (2011).

${ }^{10}$ Eyal Benvenisti, Exit and Voice in the Age of Globalization, 98 MICH. L. REV. 167, 188-89 (1999) (describing courts' "extreme deference to the executive" in foreign affairs as "enabl[ing] a sizable amount of executive activity, having major ramifications on domestic interests, to remain completely beyond judicial reach and effective public scrutiny"); Stein, supra note 1, at 531 (describing lack of parliamentary scrutiny of international organizations).

${ }^{11}$ See, e.g., Kenneth Abbott \& Duncan Snidal, Why States Act Through Formal International Organizations, 42 J. CONFLICT RESOL. 3, 18 (1998) (suggesting that international financial institutions offer the executive branch a way to circumvent Congress's preferences on distributing foreign aid); see also ALVAREZ, supra note 3, at 396 ("[T] reaty-making may enhance the power of executive branches within governments, at the expense of national parliaments or legislatures, and sometimes permits the executive branch to accomplish legal changes that it alone could not accomplish or, in those states that accord treaties superior status to a national constitution, even to take legal actions otherwise not authorized to any branch of government.”). 
crises. ${ }^{12}$ Over the past forty years, Congress has undertaken persistent and often successful efforts to shape day-to-day U.S. participation in the Bank, a key international organization. Some of Congress's methods for doing so may contravene constitutional limits on its authority, but the executive branch's protestations to that effect have not held Congress back.

By focusing on Congress's ongoing role in influencing the Bank's operations, this article addresses a perplexing oversight in the literature concerning the democratic accountability of international organizations in the United States. To the extent that this literature considers Congress at all, it has focused narrowly on two discrete points: Congress's role in the initial decision to authorize U.S. participation in international organizations and its role in implementing new international legal obligations that these organizations generate. ${ }^{13}$ But limiting the inquiry to these discrete points misses much of what is important. First, international organizations are durable institutions with long lives; the Bank, for example, has been around since 1945. Concerns about democratic accountability do not wane over time. To the contrary, they are likely to grow more acute. ${ }^{14}$ Second, many international organizations, including the Bank, conduct their mandated activities without generating new international norms that bind their member states, with the consequence that their activities do not raise the question of whether implementing legislation is necessary. ${ }^{15}$

To understand the nature and extent of Congress's involvement in shaping Bank policy, one should start with the U.S. Code. Congress has enacted scores of instructions regarding the Bank. Some of these instructions direct the U.S. representatives at the Bank how to vote. Others direct the U.S. representatives at the Bank to promote or oppose a specified policy. The Department of the Treasury's compilation of legislative mandates that govern interactions with the Bank and other international financial institutions runs nearly 250 pages. ${ }^{16}$

These legislated instructions are striking for at least two reasons. First, the obstacles that hinder congressional action have not prevented Congress from adopting legislation regarding the Bank-and from doing so on a regular, ongoing basis over a period exceeding forty years.

${ }^{12}$ As treaties cover an increasingly broad and diverse range of subjects, wars and crises are making up a smaller share of the foreign affairs field. See, e.g., Richard B. Stewart, U.S. Administrative Law: A Model for Global Administrative Law? 68 LAW \& CONTEMP. PROBS. 63, 63-64 (2005) (observing "explosive development of a great variety of international economic and social regulatory regimes" in recent decades).

13 See, e.g., Oona A. Hathaway, Treaties' End, 117 YALE L.J. 1236, 1308-12 (arguing that congressional-executive agreements approved by majorities of both houses are more democratic than treaties approved by two-thirds of the Senate); McGinnis, supra note 2; Curtis A. Bradley, International Delegations, The Structural Constitution, and Non-Self-Execution, 55 STANFORD L. REV. 1557 (2003); JULIAN KU \& JOHN YOO, TAMING GLOBALIZATION 87-1 12 (2012). An exception is Anne-Marie Slaughter, who describes growing efforts to develop international networks of legislatures and legislators to influence international organizations. ANNE-MARIE SLAUGHTER, A NEW WORLD ORDER 104-30 (2004).

${ }^{14}$ Stein, supra note 1, at 531 ("At the national level, experience has shown that the legitimacy of a state's adhesion to an IGO [intergovernmental organization], grounded in the act of approval by an elected legislature, dissipates quickly as the national delegation, appointed and instructed by the national executive, often acts within the organization in alliance with other delegations and IGO staff, and finds itself with little actual supervision by, or accountability to, the legislature.").

${ }^{15}$ More precisely, the Bank does not impose obligations on member states unless they borrow from it. Laurence Boisson de Chazournes, Policy Guidance and Compliance: The World Bank Operational Standards, in COMMITMENT AND COMPLIANCE: THE ROLE OF NON-BINDING NORMS IN THE INTERNATIONAL LEGAL SYSTEM 289 (Dinah Shelton ed., 2000). For other examples of international organizations that do not impose binding obligations, see, for example, COMMITMENT AND COMPLIANCE, supra; Curtis A. Bradley \& Judith G. Kelley, The Concept of International Delegation, 71 LAW. \& CONTEMP. PROBS. 1, 14-16 (2008).

${ }^{16}$ DEP'T OF THE TREASURY, DEPARTMENT OF THE TREASURY COMPILATION OF LEGISLATIVE MANDATES APPLYING TO U.S. PARTICIPATION IN THE IFIS (10th ed. 2010). 
Second, the legislated instructions reflect a constitutionally contested assertion of authority over decisions that would otherwise be made unilaterally by the executive branch. ${ }^{17}$ Every president since George H. W. Bush has issued signing statements objecting that these legislated instructions impinge on the president's exclusive constitutional authority to engage in international negotiations. ${ }^{18}$

Of course, it is one thing to legislate voting or negotiation instructions. It is another thing to see that they are carried out, especially when the president has asserted constitutional objections. And it is still more challenging for Congress to motivate the executive branch to pursue the policies underlying the legislated instructions with any kind of energy, enthusiasm, or serious intent. And yet, when it comes to voting instructions, Congress's track record is good. In Republican and Democratic administrations and during periods of both unified and divided government, the executive branch has voted consistently with Congress's instructions. ${ }^{19}$ Congress has enjoyed some significant successes in spurring the executive branch to embrace specific policy shifts. Most remarkably, Congress succeeded in turning Reagan administration officials into effective advocates of reforming the Bank's approach to environmental issues.

Congress's most important tool for achieving these outcomes is a familiar source of leverage: threatening to cut the Bank's funding. ${ }^{20}$ Congress has deployed this threat repeatedly and successfully, both to spur action on particular policy goals and to defend its constitutional authority to issue negotiation and voting instructions. ${ }^{21}$ Monitoring, while less dramatic than threats to cut funding, has also proved an important tool to ensure that the executive branch undertakes more than rote implementation of Congress's legislated instructions. In addition to holding hearings and requiring the executive branch to draft reports, Congress has successfully pursued changes in the Bank's transparency policies that have reinforced Congress's ability to monitor not only the Bank but also executive branch officials' interactions with it. ${ }^{22}$

In short, critics have underestimated Congress. At least when it comes to the United States and the Bank, there is little foundation for the claim that participation in an international organization allows the executive branch to sideline Congress. Congress can and does protect its institutional prerogatives, and its active involvement in this especially important international organization has been ongoing - the rule rather than the exception. There is also reason to think that Congress might enjoy similar success in other international organizations: the feature of the Bank that has been most important to Congress's success-the Bank's regular

\footnotetext{
${ }_{17}^{17}$ See infra part II.

${ }^{18}$ These constitutional debates have received surprisingly little attention in the literature about the Bank. See infra note 53 and accompanying text.

${ }^{19}$ Daryl Levinson and Rick Pildes argue that the dynamics between Congress and the president are largely determined by whether government is divided or unified by political party. Daryl J. Levinson \& Richard H. Pildes, Separation of Parties, Not Powers, 119 HARV. L. REV. 2311 (2006). Political party affiliation appears to be relatively unimportant to understanding dynamics regarding the Bank. Congress has enacted numerous voting and negotiation instructions during periods of unified government. The most prominent fight over the constitutionality of Congress's legislated instructions took place during a period of unified government at the beginning of President Obama's first term. And Congress has legislated instructions that have been energetically implemented during periods of divided government.

${ }^{20}$ See infra part III.

${ }^{21}$ See infra part IV.

${ }^{22}$ See infra part V.
} 
need for funding - is shared by most international organizations in which the United States participates. $^{23}$

This article does not set forth a theory of the democratic accountability of international organizations, but it does highlight some reasons why caution is warranted in assessing the implications of congressional participation for the democratic accountability of international organizations. The negative claim that international organizations undermine democracy by enfeebling national legislatures suggests two positive claims: that legislative participation is necessary to cure democratic deficits and that active legislative participation actually would cure democratic deficits. Neither is obviously correct. On the first point, legislative participation may not be necessary to cure democratic deficits because, in the absence of congressional involvement, the executive branch delineates Bank policy and is itself headed by a democratically accountable actor- the president. The president's foreign policy views play a role in his election and influence the policies that the Treasury Department pursues regarding the Bank. An active Congress may diminish the president's ability to pursue his chosen foreign policy strategies and to achieve his foreign policy goals.

With respect to the second claim, this article's account of congressional participation in shaping Bank policy highlights some counterintuitive tensions between congressional activism and democratic accountability. ${ }^{24}$ The tools that Congress has deployed to shape Bank policy are noteworthy in part because they do not necessarily involve the virtues commonly associated with congressional involvement - namely, deliberation and a high level of consensus among a large group of electorally accountable individuals reflecting the views of geographically discrete constituencies. ${ }^{25}$ Since the 1980s, the overwhelming majority of legislated instructions have been adopted as riders to large appropriations bills. Such riders are generally not the product of a transparent, inclusive, and deliberative process. ${ }^{26}$ Likewise, the threats to cut funding that proved so effective at motivating the executive branch can be credibly deployed by a single senator or representative, provided that he or she chairs the right committee or subcommittee. These tools for influencing Bank policy allow Congress to avoid the collective action problems that often hamper it in the foreign affairs field. ${ }^{27}$ But the more that Congress relies on tools that engage only a small handful of its members, the harder it is to see congressional action as ensuring that the positions staked out by the executive branch reflect the will of the American people.

That said, by carving out a role for itself in shaping day-to-day Bank policy, Congress has cracked open a closed process within the executive branch to a richer range of input and a wider

${ }^{23}$ See infra part VI (addressing the generalizability of the Bank example).

${ }^{24}$ Other commentators have argued that international organizations may enhance liberal democratic governance even if they do undermine legislatures. See Keohane, supra note 2 (arguing that participation in international organizations enhances democracy by limiting the power of special interest factions, protecting individual rights, and improving the quality of democratic deliberation); Kal Raustiala, Rethinking the Sovereignty Debate in International Economic Law, 6 J. INT'L ECON. L. 841 (2003).

${ }_{25}$ See, e.g. , Jide Nzelibe, The Fable of the Nationalist President and the Parochial Congress, 53 UCLA L. REV. 1217, 1249 (2006).

${ }^{26}$ See, e.g. Jack Beermann, Congressional Administration, 43 SAN DIEGO L. REV. 61, 88 (2006) ("riders . . often fly below the political radar, placed in the bill by a few connected members of Congress"); Thomas McGarity, Administrative Law as Blood Sport: Policy Erosion in a Highly Partisan Age, 61 DUKE L.J. 1671 (2012) (describing riders as "the tools of special-interest lobbyists with access to key congressional players").

${ }^{27}$ See supra note 9. 
circle of democratically accountable officials. ${ }^{28}$ Congress has identified problems at the Bank of which the executive branch was unaware, and has called them to the administration's attention. Congress's instructions (including those adopted as appropriations riders) have contributed to both public debates and substantive outcomes by requiring executive branch officials to publicly defend — and perhaps rethink - their preferred policy outcomes and methods for pursuing them. ${ }^{29}$ Congress's involvement thus can contribute positively to both the substance of U.S. policy and the process by which it is determined.

\section{INTRODUCTION TO THE WORLD BANK}

What is commonly referred to as the World Bank is actually a cluster of five legally distinct international organizations. The two most significant are the International Bank for Reconstruction and Development (IBRD) and the International Development Association (IDA). For readability's sake, this article will refer to the IBRD and IDA together as "the World Bank," or Bank, distinguishing between them only as necessary. The IBRD, along with the International Monetary Fund (IMF), was established in 1945 following negotiations in Bretton Woods, New Hampshire. ${ }^{30}$ The IBRD's primary activity is extending loans to governments for development purposes; today the IBRD describes its overriding goal as "to overcome poverty and improve standards of living." 31

In order to lend money, of course, a bank needs capital. The IBRD gets funding from two main sources: directly from its member states and by selling debt securities in the private capital markets. ${ }^{32}$ Income from the IBRD's loans constitutes a third source. ${ }^{33}$ Significantly, this financing structure means that the IBRD does not require annual contributions from its member states.

The IBRD's member states supervise and direct its activities through two bodies: the Board of Governors and the executive directors. Every member state is represented on the Board of

\footnotetext{
${ }^{28}$ As Kathryn Lavelle describes, shifting constellations of interest groups have both supported, and sought to influence, the Bank and the IMF since their establishment in 1945. Quite often these interest groups have demanded that Congress pursue policy changes at the Bank and the IMF as a condition of their support for funding these institutions. The extent to which Congress has embraced these demands for change has varied over time. To explain this variation, Lavelle focuses on exogenous shifts in the international political economy and on internal changes in how Congress operates. KATHRYN LAVELLE, LEGISLATING INTERNATIONAL ORGANIZATION (2011).

${ }^{29}$ Cf. Michael S. Barr \& Geoffrey P. Miller, Global Administrative Law: The View from Basel, 17 EUR. J. INT'L L. 15, 32-33 (2006) (describing how public disagreement among U.S. agencies over negotiations concerning international financial regulation can help the public identify key issues in dispute and can contribute to more reasoned decision making).

${ }^{30}$ Articles of Agreement of the International Monetary Fund, July 22, 1944, 60 Stat. 1401, 2 UNTS 39; Articles of Agreement of the International Bank for Reconstruction and Development, July 22, 1944, 60 Stat. 1440, 2 UNTS 134 [hereinafter IBRD Agreement].

31 WORLD BANK, THE WORLD BANK ANNUAL REPORT 2011: YeAR IN REVIEW 2 (2011).

${ }^{32}$ Since 1946, members have paid into the Bank about $\$ 11$ billion in capital. This amount represents only a small fraction of each member's capital stock subscription; the rest is subject to call should the Bank become unable to pay its obligations. IBRD Agreement, supra note 30 , Art. II, $\$ 5$. The callable capital has helped the Bank to maintain a triple-A rating since 1959. See World Bank, How IBRD Is Financed, at http://go.worldbank.org/LAG4BZ1VD1; SARAH BABB, BEHIND THE DEVELOPMENT BANKS 35 (2009).

${ }^{33}$ In fiscal year 2011, the Bank's profits totaled $\$ 996$ million. WORLD BANK, supra note 31. This income covers the IBRD's operating expenses, goes into reserves to strengthen the Bank's balance sheet, and provides an annual transfer to the IDA. See World Bank, supra note 32 .
} 
Governors, usually by that state's secretary of treasury or equivalent. ${ }^{34}$ As a formal matter this body is vested with "[a]ll the powers of the Bank," 35 but in practice the executive directors run the bank. ${ }^{36}$ There are twenty-five executive directors. Each of the five largest capitalcontributing states appoints an executive director. (The president of the United States appoints the U.S. executive director with the advice and consent of the Senate. $)^{37}$ The IBRD's other members elect the remaining twenty executive directors. Each of these executive directors represents a group of member states, ${ }^{38}$ and each casts the aggregate number of votes allocated to the members that he or she represents. ${ }^{39}$ Among other things, the executive directors approve every loan that the IBRD makes by majority of votes cast.

Unlike most other international organizations, the IBRD does not operate on a one-state, one-vote basis. Instead, members' votes are weighted by their capital contributions. ${ }^{40}$ The United States has the most votes: today it casts just over 15 percent of the total votes ${ }^{41}$-a thousand times more votes than Palau, which casts the fewest. ${ }^{42}$ The United States has never had a formal veto over run-of-the-mill decisions by the executive directors and Board of Governors, but its voting share does allow it to veto amendments to the IBRD's charter. ${ }^{43}$

The executive directors together select the Bank's president, who is charged with conducting its ordinary business. ${ }^{44}$ As head of the Bank's management and staff, the president plays a key role in setting the bank's direction. By tradition-but not by requirement in the charter-the president has to date always been an American. ${ }^{45}$ The charter provides that the president, like the rest of the Bank's staff, is to be an international civil servant loyal only to the bank. ${ }^{46}$ The Bank president can be dismissed only by a decision of the executive directors. ${ }^{47}$

\footnotetext{
${ }^{34}$ See http://siteresources.worldbank.org/BODINT/Resources/278027-1215526322295/BankGovernors.pdf (listing names and titles of IBRD and IDA governors).

${ }^{35}$ IBRD Agreement, supra note 30 , Art. V, $\$ 2$ (a). The board can delegate nearly all of its powers to the executive directors. Id., Art. V, $\$ 2(\mathrm{a})$, (b).

${ }^{36}$ The Board of Governors meets too rarely and is "too large a body to do more than ratify proposals put to it and serve as a general indicator of trends of thought." EDWARD S. MASON \& ROBERT E. ASHER, THE WORLD BANK SINCE BRETTON WOODS 63 (1973).

${ }^{37}$ The Bretton Woods Agreements Act, Pub. L. No. 79-171, \$3(a), 59 Stat. 512 (1945) [hereinafter BWAA].

${ }^{38}$ IBRD Agreement, supra note 30, Art. V, \$4(b).

$39 \mathrm{Id}$., $\$ 4(\mathrm{~g})$.

${ }^{40} I d ., \$ 3(\mathrm{a}),(\mathrm{b})$.

${ }^{41}$ World Bank, International Bank for Reconstruction and Development Subscriptions and Voting Power of Member Countries (June 30,2013), at http://siteresources.worldbank.org/BODINT/Resources/278027-1215524804501/ IBRDCountryVotingTable.pdf (noting that the United States casts 297,459 votes out of a total of 1,956,440 votes, or 15.2 percent).

${ }^{42}$ Id. (noting that Palau casts 594 votes out of a total of 1,956,440 votes, or 0.03 percent).

${ }^{43}$ IBRD Agreement, supra note 30, Art. VIII(a) (requiring approval of amendments by members having 85 percent of total voting power).

${ }^{44} I d$., Art V, $\$ 5(\mathrm{a})$, (b); see also infra note 51.

45 See Jacob Katz Cogan, Representation and Power in International Organization: The Operational Constitution and Its Critics, 103 AJIL 209 (2009); Catherine Gwin, U.S. Relations with the World Bank, 1945-1992, in 2 THE WORLD BANK: ITS FIRST HALF CENTURY 195, 246 (Devesh Kapur, John Prior Lewis \& Richard Webb eds., 1997) ("This prerogative was initially granted not only because the United States was the Bank's largest shareholder but also because it was the key guarantor and principal capital market for Bank bonds.").

${ }^{46}$ The Bank's president, officers, and staff "owe their duty entirely to the Bank and to no other authority"; the Bank's members are obligated to "respect the international character of this duty" and to "refrain from all attempts to influence any of them in the discharge of their duties." IBRD Agreement, supra note 30, Art. V, $\$ 5(\mathrm{c})$.

${ }^{47} I d ., \$ 5(\mathrm{a})$.
} 
The International Development Association was established in 1960 to support economic development in states that are too poor or insufficiently creditworthy to borrow from the IBRD. ${ }^{48}$ The typical terms for IDA loans are highly concessional- that is, their terms are so generous that in reality they are more grants than loans. ${ }^{49}$ Formally, the IDA is a separate international organization from the IBRD. On the ground, however, the two institutions are inextricable. ${ }^{50}$ The IDA shares the IBRD's president, executive directors, governors, office space, and staff. ${ }^{51}$ The IDA's decision-making structure is nearly identical to that of the IBRD. ${ }^{52}$ The concessional nature of the IDA's loans produces the biggest difference between the IBRD and the IDA: unlike the IBRD, the IDA requires regular infusions of new funds from its member states, which typically agree to replenish the IDA's coffers every three years. As explained in part III below, this feature of the IDA significantly strengthens Congress's hand when it comes to shaping policy concerning both the IBRD and IDA.

\section{LEGISLATING NEGOTIATION AND VOTING INSTRUCTIONS}

Although Congress's instructions for negotiation and voting began to proliferate during the 1970s, the first example of such an instruction dates back to 1945 . These instructions are quite possibly unconstitutional. ${ }^{53}$ And yet, no president before George H. W. Bush contested their constitutionality. Without delving into the substance of the constitutional question, this section seeks to explain why the executive branch failed to object on constitutional grounds during the Bank's first several decades.

${ }^{48}$ MASON \& ASHER, supra note 36, at 383.

${ }^{49}$ IDA loans, or "credits," typically carry no or low interest charges, have grace periods of five to ten years, and are repaid over a period of twenty-five to forty years. The IDA also provides some outright grants. World Bank, What Is IDA?, at http://go.worldbank.org/ZRAOR8IWW0.

${ }^{50}$ MASON \& ASHER, supra note 36, at 380-81 ("As an international organization affiliated with the World Bank, IDA is an elaborate fiction. Called an 'association,' and possessed of Articles of Agreement, officers, governmental members galore, and all the trappings of other international agencies, it is as yet simply a fund administered by the World Bank."); Ronald T. Libby, International Development Association: A Legal Fiction Designed to Secure an LDC Constituency, 29 INT'L ORG. 1065 (1975).

${ }^{51}$ Articles of Agreement of the International Development Association, Art. VI, Jan. 26, 1960, 11 UST 2284, 439 UNTS 249; see also International Development Association Act, Pub. L. No. 86-565, \$3, 74 Stat. 293 (June 30, 1960).

52 Articles of Agreement of the International Development Association, supra note 51, Art. VI, \$3; World Bank Group Finances: IDA Voting Power, at https://finances.worldbank.org/Shareholder-Equity/IDA-Voting-Power/ 4g6v-z4mt.

${ }^{53}$ Most of the literature on the Bank assumes that Congress has the authority to issue such instructions. Jonathan Sanford, for example, observes without comment that "the President and Congress both have this power [to instruct the executive director] and both are inclined to use it." Jonathan Earl Sanford, U.S. Policy Toward the Multilateral Development Banks: The Role of Congress, 22 GEO. WASH. J. INT'L L. \& ECON. 1, 15 (1988) (emphasis added); see also Daniel L. Nielson \& Michael J. Tierney, Delegation to International Organizations: Agency Theory and World Bank Reform, 57 INT'L ORG. 241, 255-56 (2003) ("Also, Congress can dictate the votes of the director by statute (subject to veto and overrides, of course)."). Thomas Franck and Edward Weisband observe that the "making... of . . . country-by-country rules" regarding votes in the international financial institutions is "clearly more appropriate to the executive than the legislative branch," but they do not directly assess the instructions' constitutionality. THOMAS M. FRANCK \& EDWARD WEISBAND, FOREIGN POLICY BY CONGRESS 93 (1979). Ian Bowles and Cyril Kormos briefly consider and ultimately reject constitutional objections to legislated instructions. Ian A. Bowles $\&$ Cyril F. Kormos, Environmental Reform at the World Bank: The Role of the U.S. Congress, 35 VA. J. INT'L L. 777, 813-19 (1995). Kathryn Lavelle mentions the dispute over a signing statement issued by President Obama in 2009 but does not address other signing statements or debates over the scope of the president's exclusive negotiation authority. See LAVELLE, supra note 28, at 166. 


\section{The Constitutional Question}

The text of the Constitution does not explicitly allocate negotiation authority. The primary constitutional sources for the president's negotiation authority include the president's authority under Article II to "make treaties" and to "receive Ambassadors and other public Ministers." ${ }^{54}$ These explicit grants of authority have been interpreted to confer on the president substantive discretion regarding at least two important foreign affairs decisions: whether to recognize particular governments and whether to follow through and ratify international agreements after obtaining the consent of two-thirds of the Senate. ${ }^{55}$

Whether the president retains comparable discretion with respect to other decisions or communications on the international plane — such as how to vote on a particular Bank loan-remains contested. The Supreme Court has, on several occasions, confirmed that the president is "the constitutional representative of the United States in its dealings with foreign nations." 56 But these kinds of statements do not address whether the president has exclusive authority to determine the substantive content that he will communicate. ${ }^{57}$ The Court of Appeals for the Ninth Circuit has declined to enforce a statutory requirement that the executive branch negotiate treaties to protect sea turtles, reasoning that it violated the separation of powers by infringing on the president's exclusive negotiation authority. ${ }^{58}$ But commentators remain divided. ${ }^{59}$

Presidents are usually quick to object to perceived incursions into their constitutional authority: they have both the institutional capacity and the incentive to do so. ${ }^{60}$ The prominent role of practice in resolving separation-of-powers disputes in the foreign affairs field supplies

${ }^{54}$ U.S. CONST. Art. II, $\$ \$ 2,3$; see also David J. Barron, Office of Legal Counsel, Constitutionality of Section 7054 of the Fiscal Year 2009 Foreign Appropriations Act 4-5 (June 1, 2009), at http://www.justice.gov/olc/2009/ section7054.pdf.

55 See Banco Nacional de Cuba v. Sabbatino, 376 U.S. 398, 410 (1964); Goldwater v. Carter, 444 U.S. 996, 1007 (1979) (Brennan, J., dissenting); CURTIS A. BRADLEY \& JACK L. GOLDSMITH, FOREIGN RELATIONS LAW 479 (4th ed. 2011).

${ }^{56}$ United States v. Louisiana, 363 U.S. 1, 35 (1960); see also United States v. Curtiss-Wright Export Corp., 299 U.S. 304, 319 (1936); Ex parte Hennen, 38 U.S. (13 Pet.) 225, 235 (1839).

57 See, e.g., EDWARD S. CORWIN, THE PRESIDENT: OFFICE AND POWERS, 1787-1984, at 208 (5th rev. ed. 1984) ("[W] hile the President alone may address foreign governments and be addressed by them, yet in fulfilling these functions he is, or at least may be, the mouthpiece of a power of decision that resides elsewhere."). Putting this question in the framework that Justice Jackson sets out in his concurrence in Youngstown Sheet \& Tube Co. v. Sawyer, the question is whether the president's power is "preclusive" and allows him to "take[ ] measures incompatible with the expressed or implied will of Congress" regarding the positions that he or other members of the executive branch will stake out. Youngstown Sheet \& Tube Co. v. Sawyer, 343 U.S. 579, 637-38 (1952); see also David J. Barron \& Martin S. Lederman, The Commander in Chiefat the Lowest Ebb_Framing the Problem, Doctrine, and Original Understanding, 121 HARV. L. REV. 689, 691-98 (2008).

${ }^{58}$ Earth Island Institute v. Christopher, 6 F.3d 648, 652 (9th Cir. 1993).

${ }^{59}$ Compare LOUIS HENKIN, FOREIGN AFFAIRS AND THE US CONSTITUTION 249 ( $2 \mathrm{~d}$ ed. 1996) (“Attempts by Congress to instruct U.S. representatives [to international organizations] are highly questionable as a matter of constitutional separation of powers, and are usually only hortatory or are likely to be treated as such by the President."), and H. Jefferson Powell, The President's Authority over Foreign Affairs: An Executive Branch Perspective, 67 GEO. WASH. L. REV. 527, 558-59 (arguing that the executive branch has the exclusive authority to determine the time, scope, and objectives of all negotiations), with Lori Fisler Damrosch, Treaties and International Regulation, 98 ASIL PROC. 349, 351(2004) (describing the Justice Department's position that statutes cannot direct the president to vote a certain way in an international forum as "wrong as a matter of democratic political theory, historical experience, common sense, and constitutional law”); see also Bowles \& Kormos, supra note 53, at 813-19; Edward Swaine, International Organizations (2012) (unpublished manuscript) (on file with author) (suggesting that the constitutional analysis may depend on the type of instruction at issue).

${ }^{60}$ Moe \& Howell, supra note 5, at 145; Bradley \& Morrison, supra note 8. 
one incentive. ${ }^{61}$ By acceding to legislated negotiation and voting instructions, the executive builds support for the proposition that such instructions are, in fact, constitutional. ${ }^{62}$

For this reason, the absence of constitutional objections from the executive branch until the late 1980s presents something of a puzzle. The best explanation is that implementing the negotiation and voting instructions generally imposed low costs on the executive branch. Congress's instructions were frequently drafted in a way that allowed the executive branch to avoid triggering them. When the instructions precluded wriggling out in this way, the Bank's voting rules limited the consequences of implementing Congress's instructions. Although the United States casts a disproportionate share of the votes at the Bank, its voting power has never been large enough to determine singlehandedly whether individual loans are approved. As a result, the U.S. executive director could follow Congress's instructions to oppose a particular loan, confident that it would still be approved by the other executive directors. This is not to suggest that complying with Congress's voting instructions is completely cost free, however: U.S. executive directors have remonstrated that when the U.S. vote is predetermined by legislation, the United States loses influence and the ability to shape the terms of particular loans. ${ }^{63}$

\section{The First Legislated Instructions}

Congress's first legislated instructions date back to the Bretton Woods Agreements Act (BWAA), the 1945 legislation that authorized the United States' participation in the IBRD and the IMF. In the BWAA, Congress directed the U.S. representatives at the Bank to "obtain promptly an official interpretation by the Bank as to its authority to make or guarantee loans for programs of economic reconstruction and the reconstruction of monetary systems, including long-term stabilization loans." ${ }^{64}$ In the event that the efforts to secure this interpretation failed, Congress directed the U.S. representatives to propose, support, and accept an amendment to that effect. ${ }^{65}$ The BWAA also included complementary instructions to the IMF governor and executive director to obtain an official interpretation confirming that the IMF lacks comparable authority. ${ }^{66}$

\footnotetext{
${ }^{61}$ See Youngstown, 343 U.S. at 610-11 (Frankfurter, J., concurring); Mortenson, supra note 9, at 377-78; see also Peter Spiro, War Powers and the Sirens of Formalism, 68 N.Y.U. L. REV. 1338, 1355 (1993) (describing how war powers law is developed by "an accretion of interactions among the branches, that gives rise to basic norms governing the branches' behavior in the area").

${ }^{62}$ Cf. Barron \& Lederman, supra note 57, at 697 (arguing that Congress has enacted restrictions on the conduct of military campaigns "too often, and Presidents challenged their legality too infrequently ..., for anything like a tradition of preclusive power to have taken root"); David J. Barron \& Martin S. Lederman, The Commander in Chief at the Lowest Ebb-A Constitutional History, 121 HARV. L. REV. 941, 1101 (2008) (arguing that this history of congressional regulation coupled with executive acquiescence also "casts doubt on the functionalist contention that a President cannot possibly conduct a war so long as he understands himself to be subject to legislatively imposed restrictions").

${ }^{63}$ Robert B. Holland III, Op-Ed., The Real World Bank Scandal, WALL ST. J., Apr. 20, 2007, at A15 (former U.S. executive director describing legislatively mandated voting requirements as "mind-numbing and influence diminishing"); telephone interview with Jan Piercy, former U.S. Executive Director of the World Bank (May 7, 2012) (explaining that other executive directors have little reason to accept modifications to loan terms proposed by the United States when there is no chance that accepting the U.S. proposal would shift the U.S. vote).

${ }^{64}$ BWAA, supra note $37, \$ 12$.

${ }^{65} \mathrm{Id}$.

${ }^{66} I d ., \$ 13$.
} 
The BWAA's legislative history and the broader context of its enactment suggest two interrelated reasons why the executive branch declined to object to this initial set of voting instructions. The executive branch placed a high priority on Congress's accepting the Bretton Woods agreements without reservations or amendments because it did not want to reopen international negotiations. ${ }^{67}$ The rest of the world was watching: Congress was considering these agreements before any other state that had participated in the negotiations at Bretton Woods. The United States' rejection of the League of Nations still loomed large.

And yet, key members of Congress initially refused to accept the Bretton Woods agreements as drafted, largely due to concerns about the IMF. ${ }^{68}$ They took seriously the arguments made by opponents, including the American Banking Association, whose members feared that extensive borrowing from the IMF to address major, long-term economic challenges would deplete the IMF's funds. ${ }^{69}$ They wanted to amend the IMF agreement to make sure that any such loans would be made by the IBRD rather than the IMF. ${ }^{70}$ The Treasury Department indicated its willingness to support long-term loans only at the IBRD but opposed amending either agreement. The IMF's opponents, however, were not content to rely exclusively on the Treasury Department's assurances. ${ }^{71}$

This left the Bretton Woods supporters with a challenge: how to provide Congress with a stronger commitment to comply with its views on permissible uses of the IMF without amending the IMF or IBRD agreement. The legislated instructions supplied a mutually acceptable solution. They required the Treasury Department to confirm — officially — the interpretations that would placate the IMF's opponents. ${ }^{72}$ Meanwhile, the executive branch was able to secure approval for the IMF and IBRD agreements without amendment or reservation. Had the executive branch raised constitutional objections to such instructions, this particular solution would not have been possible.

The administration's eagerness to establish congressional-executive agreements as a constitutionally permissible method to approve international agreements suggests an additional reason why the executive branch declined to invoke constitutional arguments to fend off legislated instructions. The administration sought approval of the Bretton Woods agreements from a majority of both houses of Congress rather than two-thirds of the Senate (as Article II of the Constitution requires), and worked hard to make the case that this option was constitutional. During the early and mid-1940s, the extent to which the two-house procedure could substitute for approval by two-thirds of the Senate was hotly contested. ${ }^{73}$ State and Treasury Department officials argued that legislation was a particularly appropriate mechanism for authorizing U.S.

\footnotetext{
${ }^{67}$ See, e.g., Hearings on H.R. 2211 Before the H. Comm. on Banking and Currency, 79th Cong. 253 (1945) [hereinafter Hearings on H.R. 2211] (statement of Dean Acheson, assistant secretary of state).

${ }^{68}$ See, e.g., RiCHARD N. GARDNER, STERLING-DOLLAR DiPLOMACY 129-43 (1969); LAVELLE, supra note 28 , at 39-61.

${ }^{69}$ See Hearings on H.R. 2211, supra note 67, at 734-35 (statement of Ralph Flanders, president of the Federal Reserve Bank, Boston, and chairman, Research Committee, Committee for Economic Development); LAVELLE, supra note 28 , at $46-61$.

${ }^{70}$ Hearings on H.R. 2211, supra note 67, at 735 .

${ }^{71} \mathrm{Id}$. at 743 .

${ }^{72}$ W. Randolph Burgess, president of the American Bankers Association, praised the amended bill and noted that it included several of the ABA's recommendations. Burgess Praises Bretton Changes, N.Y. TiMES, May 26, 1945, at 21.

73 See Bruce Ackerman \& David Golove, Is NAFTA Constitutional?, 108 HARV. L. REV. 799, 861-96 (1995).
} 
participation in the Bank and the IMF in light of the overlap between the subject matter of the Bretton Woods agreements and Congress's authority under Article I, Section 8, of the Constitution. ${ }^{74}$ The State and Treasury Departments also cited the large volume of existing legislation related to the subject matter of the Bretton Woods agreements, noting that "there are few examples of an international agreement which affect so intimately the powers of Congress in such important fields or which so directly affect such a complex pattern of legislation already enacted and congressional policy already enunciated." 75 It would have been awkward for the executive branch to object to negotiation instructions on constitutional grounds while at the same time it was, in defending the constitutionality of congressional-executive agreements, emphasizing the appropriateness of congressional involvement.

In any event, the U.S. executive director followed the negotiation instructions contained in the BWAA and, at the inaugural meeting of the Bank's member states, requested Congress's preferred interpretation of the Bank's authority. Treasury Department officials had told members of Congress that they did not expect it to be a tough sell. ${ }^{76}$ And, indeed, the Treasury Department was able to deliver: the Bank's executive directors adopted the United States' proposal. ${ }^{77}$ Not long thereafter, the IMF adopted the complementary interpretation that Congress had instructed the Treasury Department to pursue. ${ }^{78}$

\section{Legislated Instructions Become Commonplace}

After a quarter-century gap, Congress started legislating instructions with increasing regularity. ${ }^{79}$ In 1972, at the behest of Representative Henry Gonzales, Congress enacted the first set of voting instructions to the U.S. executive director. ${ }^{80}$ The instructions required the U.S. executive director to oppose loans to countries that had expropriated U.S. property, unless the president determined that adequate compensation was being negotiated or had been paid. ${ }^{81}$ These instructions appeared not to faze the executive branch. One reason is that the instructions coincided with preexisting executive branch policy. ${ }^{82}$ They also tracked the Bank's preexisting policy (adopted under pressure from the United States) against lending to countries that expropriated foreign property without compensation. ${ }^{83}$ What is more, the legislated instructions left the executive branch with considerable discretion in deciding whether a waiver

\footnotetext{
${ }^{74}$ Bretton Woods Agreements Act: Hearings on H.R. 3314 Before the S. Comm. on Banking \& Currency, 79th Cong. 533 (1945) [hereinafter Hearings on H.R. 3314].

${ }^{75} \mathrm{Id}$. at 537.

${ }^{76} \mathrm{Id}$. at 224.

77 NATIONAL ADVISORY COUNCIL ON INTERNATIONAL MONETARY AND FINANCIAL PROBLEMS, REPORT ON PARTICIPATION OF THE UNITED STATES IN THE FUND AND BANK TO OCTOBER 31, 1946, H.R. Doc. No. 80-53, at 8 (1947) (submitted by the president to Congress on January 13, 1947).

${ }^{78}$ Id. at 9 .

79 See infra notes 194-96 (discussing reasons for this gap).

80118 CONG. REC. 2045 (1972).

${ }^{81}$ An Act to Provide for Increased Participation by the United States in the International Development Association, Pub. L. No. 92-247, 86 Stat. 60 (1972) (codified at 22 U.S.C. 284(k)).

${ }^{82}$ H.R. REP. NO. 92-772, at 8 (1972); see also STAFF OF THE SUBCOMM. ON FOREIGN ASSISTANCE OF THE COMM. ON FOREIGN RELATIONS, 95TH CONG., U.S. POLICY AND MULTILATERAL BANKS: POLITICIZATION AND EFFECTIVENESS 9 (Comm. Print 1977) [hereinafter 1977 STAFF REPORT].

${ }^{83}$ See Lars Schoultz, Politics, Economics, and U.S. Participation in Multilateral Development Banks, 36 INT'L ORG. 537, 556 (1982); MASON \& ASHER, supra note 36, at 747.
} 
was appropriate because "adequate" compensation had been paid or because negotiations were under way. ${ }^{84}$

Also in 1972, Congress added instructions regarding the drug trade by means of a floor amendment introduced by Representative Charles Rangel. These instructions required the U.S. executive director to oppose loans to any country that the president determined had taken inadequate steps to prohibit the legal sale of narcotic drugs and other controlled substances to U.S. nationals in its territory. ${ }^{85}$ As drafted, the instructions were triggered only if the president made an explicit finding. But since the president never actually made such a finding, the instructions were never triggered. ${ }^{86}$

Two years later, in 1974, Congress adopted new voting instructions introduced by Representative Clarence Long. These instructions mandated opposition to IDA loans to countries that failed to sign the nuclear nonproliferation treaty after developing a nuclear device. ${ }^{87}$ (Because the voting instructions were added on the floor after the relevant bill made its way out of the committee, the administration did not publicly take a position on the amendment.) The instructions were targeted specifically at India, which had successfully tested a nuclear weapon the preceding May.

Unlike earlier voting instructions, these were drafted in a way that did not leave the executive branch much room for discretion:

The United States Governor is authorized and directed to vote against any loan or other utilization of the funds of the Association for the benefit of any country which develops any nuclear explosive device, unless the country is or becomes a State Party to the Treaty on the Non-Proliferation of Nuclear Weapons. ${ }^{88}$

Indeed, before these instructions were repealed in 1977, the United States cast twenty-six "no" votes against IDA loans to India. ${ }^{89}$

Even these detailed voting instructions provoked no constitutional opposition from the executive branch. In addition, their effect was limited because the instructions did not meaningfully affect the U.S. position through informal channels - the ones that mattered if the U.S. vote was to have any chance of affecting Bank policy. The administration never tried very hard to persuade other governments to emulate its vote or to dissuade bank management from proposing the kinds of loans in question. ${ }^{90}$ Notwithstanding the negative U.S. vote, the Bank's executive directors approved every one of the proposed IDA loans to India. Representative Long had anticipated the symbolic nature of the instructions. In introducing them, he explained:

\footnotetext{
${ }^{84}$ As foreign affairs scholars have noted, by drafting statutory text with vague terms, Congress delegates significant authority to the executive branch to interpret it. See, e.g., POSNER \& VERMEULE, supra note 6.

${ }^{85}$ An Act to Provide for Increased Participation by the United States in the International Development Association, Pub. L. No. 92-247, 86 Stat. 60 (1972).

${ }^{86} 1977$ STAFF REPORT, supra note 82, at 10.

${ }^{87}$ An Act to Provide for Increased Participation by the United States in the International Development Association, Pub. L. No. 93-373, \$3, 88 Stat. 445 (1974).

${ }^{88} \mathrm{Id}$.

${ }^{89}$ Schoultz, supra note 83 , at 558 . The executive branch could have argued that it is the executive director, not the governor, who votes on loans- but it chose not to invoke this technicality as a reason for disregarding the legislation.

901977 STAFF REPORT, supra note 82, at 8.
} 
All my amendment does is put America on record against nuclear proliferation.

....

In adopting this amendment, we are not binding the IDA, only our own Governor. That is all. As of January 1974, the United States has 25 percent of the vote. Fifty-one percent of the votes cast are required to reject an IDA loan.

Thus, my amendment could not by itself cut off IDA loans to any country. ${ }^{91}$

The Ford administration was the first to resist legislated voting instructions, but it objected on policy_not constitutional-grounds. In 1976, then Representative Tom Harkin introduced legislation targeting two of the regional development banks - the African Development Fund and the Inter-American Development Bank. Harkin's instructions required the U.S. executive directors of those institutions to oppose loans to any government that violated its citizens' human rights unless the loan proceeds would directly benefit needy people. ${ }^{92}$ Starting in 1973, Congress had started taking steps to reduce or eliminate U.S. foreign assistance to countries that were engaging in significant human rights violations. ${ }^{93}$ Members of Congress were outraged to discover that at the same time that U.S. aid to human rights violators like Argentina, Brazil, Chile, Indonesia, Nicaragua, the Philippines, South Korea, and Thailand was declining, multilateral aid to these same states was more than making up the difference. ${ }^{94}$ Harkin's instructions sought to align the U.S. policy on multilateral and bilateral aid, and to limit the executive branch's ability to circumvent Congress's preferences by turning to multilateral institutions to distribute resources.

Assistant Secretary of State William Rogers testified that the administration firmly opposed the Harkin Amendment. Introducing a non-economic issue into the regional development banks "smacks of paternalism," he argued, and "would make it more difficult for the U.S. government to oppose the introduction of other noneconomic preferences by other countries to these institutions." 95 Rogers's explanation alluded to a provision in the IBRD's charter that prohibits the bank and its officers from interfering in the political affairs of the bank's member states and provides that only "economic considerations shall be relevant to their decisions." 96 The meaning of this prohibition has been contested over the IBRD's history; the views of both member states and the bank's own staff as to what counts as "economic" versus "political" (and whether these two categories can even be distinguished) have shifted over time. ${ }^{97}$

91120 CONG. REC. 22,030 (1974).

${ }^{92}$ An Act to Provide for Increased Participation by the United States in the Inter-American Development Bank, Pub. L. No. 94-302, \$\$103, 211, 90 Stat. 591 (1976).

${ }^{93}$ FRANCK \& WEISBAND, supra note 53, at 85; Stephen B. Cohen, Conditioning U.S. Security Assistance on Human Rights Practices, 76 AJIL 246 (1982).

${ }^{94}$ Lars SCHOUltz, Human RightS AND United States POlicy TOWARd Latin AMERICA 282-83 (1981); FRANCK \& WEISBAND, supra note 53, at 92.

${ }_{95}$ IDB and AFDF Authorization: Hearing on H.R. 9721 Before the S. Subcomm. on Foreign Assistance of the Comm. on Foreign Relations, 94th Cong., 1st Sess. 44 (1976).

${ }^{96}$ IBRD Agreement, supra note 30, Art. IV, $\$ 10$; see also Articles of Agreement of the International Development Association, supra note 51 , Art. V, $\$ 6$ (same).

97 See, e.g., IBRAHIM F. I. SHIHATA, THE WORLD BANK IN A CHANGING WORLD 65-79 (1991); CATHERINE WEAVER, THE HYPOCRISY TRAP (2008) (describing how good governance and corruption came to be understood as appropriate topics for the Bank to address); Galit Sarfaty, Why Culture Matters in International Institutions: The Marginality of Human Rights at the World Bank, 103 AJIL 647, 658 - 65 (2009) (describing fierce contests and evolution in perspectives about whether the Bank's Articles of Agreement permit the Bank to directly address human rights). 
Notwithstanding the State Department's objections, the Harkin Amendment was adopted without opposition..$^{98}$ In the remaining months of the Ford administration, the United States cast one vote against a loan to Chile on account of the legislation. ${ }^{99}$

The following year, in 1977, the Carter administration repeated the Ford administration's objections when Harkin introduced legislation that would extend the human rights language to the IBRD and the IDA. The Carter administration opposed mandatory voting instructions even though President Carter considered human rights a centerpiece of his foreign policy. ${ }^{100}$ Hoping to placate Congress, the Carter administration suggested it would accept a milder requirement that the United States, "in connection with its voice and vote . . ., shall advance the cause of human rights, including by seeking to channel assistance toward countries other than those whose governments engage in a consistent pattern of gross violation of internationally recognized human rights." ${ }^{101}$ But the administration's proposed language was rejected. In its place, a coalition of committed human rights supporters and conservative opponents of the development banks successfully enacted legislation that mandated opposition to all loans to countries that engaged in "a consistent pattern of gross violations of internationally recognized human rights" unless the project supported by the loan would "serve the basic human needs of the citizens of such country." 102

Notwithstanding its objections, the Carter administration implemented these instructions. ${ }^{103}$ By 1980, the U.S. executive director at the World Bank had voted against, or abstained on, 112 loan proposals for human rights reasons. ${ }^{104}$ And yet, every single one of these loans was approved by the relevant multilateral development bank. ${ }^{105}$

These statistics actually understate the influence of Congress's legislation. The United States' predetermined negative vote affected the kinds of loans that the Bank management brought to the executive directors for approval. In 1977, for example, borrowing states withdrew at least a half dozen loan requests once they became aware of the legislation that mandated U.S. opposition. ${ }^{106}$ In addition, the multilateral development banks restricted their processing of loan proposals from repressive governments that did not serve the basic human needs of their citizens. As a consequence, some loan proposals that would have received a negative U.S. vote were never proposed to the executive directors for approval. ${ }^{107}$ Thus, notwithstanding

\footnotetext{
${ }^{98}$ An Act to Provide for Increased Participation by the United States in the Inter-American Development Bank, supra note 92, \$\$103, 211.

${ }^{99}$ Schoultz, supra note 83, at 559.

${ }^{100}$ Gwin, supra note 45, at 225.

${ }^{101}$ International Development Institutions Authorizations, 1977: Hearings on H.R. 5262 Before the Subcomm. on Int'l Dev. Inst. \& Fin. of the H. Comm. on Banking, Fin., \& Urban Affairs, 95th Cong. 9, 48 (1977).

${ }^{102}$ An Act to Provide for Increased Participation by the United States in the International Bank for Reconstruction and Development, the International Development Association, the International Finance Corporation, the Asian Development Bank and the Asian Development Fund, and for Other Purposes, Pub. L. No. 95-118, \$701(a)(1), (f), 91 Stat. 1067 (1977). The language closely tracks a prohibition on bilateral military assistance to human rights violators adopted in 1973. See supra note 93 and accompanying text.

${ }^{103}$ See SCHOULTZ, supra note 94, at 292-300.

${ }^{104}$ Schoultz, supra note 83, at 564.

${ }^{105} \mathrm{Id}$. at 565.

${ }^{106}$ SCHOULTZ, supra note 94, at 295.

${ }^{107}$ Id. at 295-98.
} 
objections that legislated instructions diminish the United States' influence, at least in some cases Congress's instructions can amplify it. ${ }^{108}$

Voting instructions were not the only tool on which Congress relied; it also passed legislation that directed U.S. representatives to pursue specified policies ${ }^{109}$ — as in 1978, when Congress used this tactic to supplement its human rights voting instructions. In that instance, Congress directed the president to direct the U.S. governor of the IBRD and other multilateral development banks to seek an amendment to the banks' charters that would explicitly require the banks to consider human rights in its lending decisions. ${ }^{110}$

The executive branch complied with Congress's instructions, but the vigor with which it pursued the amendment Congress desired is difficult to verify. A year later, Treasury Secretary W. Michael Blumenthal reported: "We got a unanimous reaction that such an amendment if proposed would not be adopted and that it would be argued to be contrary to certain fundamental principles in the banks.' Those principles were that 'the banks are to pursue economic criteria and not to stray afield from that." "111 Without being able to independently corroborate the positions taken by foreign governments, members of Congress had little choice but to accept the executive branch's characterizations. ${ }^{112}$

These examples illustrate the practical obstacles that Congress faces in its efforts to shape Bank policy - even when the executive branch refrains from raising constitutional objections to Congress's efforts. By the end of the 1970s, the practice of putting mandatory voting and negotiation instructions into legislation was well established. The executive branch consistently implemented the letter of the instructions. But when the executive branch did not share the underlying policy goal, those instructions failed to galvanize it to advocate vigorously for Congress's policy preferences at the Bank. Controlling the vote of the U.S. executive director gives Congress only limited influence over the Bank. Because the Bank's executive directors make decisions by majority vote, and the U.S. share of the total votes has never exceeded that threshold, the impact of determining the U.S. vote has always been limited.

The lesson of the 1970s is that meaningfully influencing Bank policy is not as simple as enacting a slew of negotiation instructions - even if those instructions are framed in mandatory terms that the executive branch implements without raising constitutional objections. ${ }^{113}$

\footnotetext{
${ }^{108}$ Robert Putnam has argued that domestic constraints can enhance a state's international bargaining position when, for example, that state's legislature must ratify the negotiated agreement before it can enter into force. Robert D. Putnam, Diplomacy and Domestic Politics: The Logic of Two-Level Games, 42 INT'L ORG. 427 (1988). Congress's ex ante voting instructions do not track this two-step model. They come closest when the U.S. executive director can credibly argue that, unless the other executive directors agree to a particular decision, Congress might withhold the next round of funding for the Bank.

109 See 1977 STAFF REPORT, supra note 82, at 11-16 (describing other examples of such instructions).

${ }^{110}$ An Act Making Appropriations for Foreign Assistance and Related Programs for the Fiscal Year Ending September 30, 1979, Pub. L. No. 95-481, \$611, 92 Stat. 1591 (1978).

${ }^{111}$ Quoted in BABB, supra note 32, at 185.

112 See subsection "Monitoring the Executive Branch" in part V, below.

${ }^{113}$ Daniel Nielson and Michael Tierney do not take this point into account when they model the relationship between the Bank and its member states in principal-agent terms. See Nielson \& Tierney, supra note 53. Nielson and Tierney acknowledge Congress's importance by modeling it as a separate and independent principal of the Bank. But Congress is not a proximate principal of the Bank. Congress must work through the executive branch to influence the Bank, and as this article explains, the executive branch has many tools available to neutralize Congress's efforts to shape Bank policy. Because Nielson and Tierney focus on environmental reform at the Bankwhere Congress enjoyed remarkable success in motivating the executive branch (and ultimately in influencing the
} 
Congress needs to persuade the U.S. executive director to engage effectively with both other member states and with the Bank's management. ${ }^{114}$ But as Congress learned when it directed advocacy of a human rights amendment, it was difficult to ensure a vigorous campaign through legislation alone. Congress's influence at the Bank would thus remain limited unless Congress found some other way to motivate the executive branch.

\section{DEPLOYING THE POWER OF THE PURSE}

Commentators have long acknowledged that Congress's ability to cut off funding may well be its most important tool in shaping foreign policy-although it is hardly an all-powerful one and can be tricky to deploy effectively. ${ }^{115}$ The first of the three subsections below describes how, after a false start, Congress used its appropriations authority to galvanize the executive branch not merely to implement the letter of voting instructions but to actively engage the Bank's management to address Congress's concerns regarding loans to Vietnam. The second subsection describes how, during the second half of the 1980s, Congress transformed the Reagan administration into an effective advocate for environmental concerns at the Bank. These examples belie the conventional account of a diminished and quiescent Congress that leaves to the executive branch the responsibility and authority to manage the United States' ongoing interactions with international organizations. ${ }^{116}$ The third subsection below discusses limits on the potential use of threats to cut funding.

At the outset it is worth noting exactly how Congress, as a collective body, accomplished its goals regarding the Bank. Although Congress does appropriate funds by passing legislation, deploying the power of the purse does not require action by Congress as a whole-or, to be more specific, does not depend on securing the agreement of majorities in both the House and Senate, in addition to the president's signature. Provided that he or she chairs the right committee or subcommittee, a single member of the House or Senate can — and frequently does credibly threaten to withhold funding. This option significantly lowers the cost of congressional action, at least for those members of Congress who hold certain leadership positions. ${ }^{117}$ To withhold funds, they do not need to solve collective action problems or prevail at the veto points that can prevent a bill from becoming a law. ${ }^{118}$

Bank), see infra part III-they do not consider the possibility that the executive branch might resist Congress's efforts.

${ }^{114}$ Gwin, supra note 45, at 244-45, 263; BABB, supra note 32.

115 See, e.g., $\mathrm{KOH}$, supra note 5, at 128-31 (describing appropriations limitations as an imperfect tool with many defects that nevertheless "remains one of Congress's few effective legal tools to regulate presidential initiatives in foreign affairs"); Moe \& Howell, supra note 5, at 147-48 (describing Congress's constitutional power to appropriate money as a "very real" but not "crippling constraint" on presidents).

116 They also illustrate how Congress can shrink the universe of actions that the president might take unilaterally. See Moe \& Howell, supra note 5.

${ }^{117}$ Compare sources cited supra note 9 (describing collective action problems and high transaction costs of congressional action).

${ }^{118}$ Cf. Bradley \& Morrison, supra note 8, at 446 (noting that Congress can more easily push back against the executive branch by using "soft law" tools that are not subject to the collective action problems that beset the formal legislative process); see also Josh Chafetz, Congress's Constitution, 160 U. PA. L. REV. 715 (2012) (describing soft law tools in greater detail). Chafetz notes that withholding money is easier than appropriating it because either the House or Senate, acting alone, can withhold money. Id. at 725. As this part explains, however, the point goes even further: some individual members of Congress can credibly threaten to withhold money. 
The legislative vehicles for Congress's negotiation and voting instructions evolved over time. Starting in the 1980s, Congress's instructions were much more likely to be "riders"—substantive provisions attached to appropriations bills. ${ }^{119}$ The dynamics surrounding appropriations legislation-especially the omnibus appropriations bills that simultaneously fund many parts of the federal government-differ from other legislation. Appropriations bills must pass to avoid shutting down the federal government, which means that individual legislators face considerable pressure to support them and that the president faces considerable pressure to sign them into law. ${ }^{120}$ These dynamics make appropriations bills attractive vehicles for substantive provisions that may lack majority support in freestanding bills. The policy merits of individual riders are less likely to have been evaluated during hearings by committees with subject-matter expertise. ${ }^{121}$ Decisions about which riders will be included in a particular appropriations bill are made by a handful of key congressional players in leadership roles; the process is not transparent. ${ }^{122}$ Finally, legislators frequently have little knowledge of the substantive provisions buried in appropriations bills that often run hundreds or, in the case of omnibus appropriations bills, thousands of pages long. ${ }^{123}$

The frequent use of these mechanisms - appropriations riders and threats to withhold funding-for formulating Bank policy is one reason why congressional action does not guarantee democratic accountability. Congressional action regarding the Bank is not necessarily the product of public debate that results in agreement among a broad cross-section of representatives. ${ }^{124}$ Whatever it means for democratic accountability, however, there is no doubt that by coupling its instructions with funding cuts, Congress can motivate the executive branch to embrace its policies and also capture the attention of the Bank's management and other executive directors. Because the United States supplies a disproportionately large share of the Bank's resources, the Bank would keenly feel any cuts. The desire to avoid such cuts may cause both the Bank's management and other executive directors to be particularly attentive to Congress's demands. In this way Congress's participation in the policymaking process can actually amplify the United States' influence when the executive branch shares Congress's policy goals. ${ }^{125}$

\section{Attemps to Restrict U.S. Funds for Bank Loans to Vietnam}

In 1977, frustrated by the limited symbolic accomplishments of previously enacted voting instructions, Representative C. W. Bill Young of Texas opted for a different tactic. He proposed legislation that would earmark appropriations to both the Bank and the regional development banks. That is, he sought to prohibit U.S. funds from being used for bank loans to

\footnotetext{
${ }^{119}$ Although internal House and Senate rules prohibit substantive provisions in appropriations legislation, these rules are often waived. Richard J. Lazarus, Congressional Descent: The Demise of Deliberative Democracy in Environmental Law, 94 GEO. L.J. 619, 636-37 (2006).

${ }^{120}$ In contrast, failure to pass a new authorization statute preserves the status quo. Id. at 634; see also GLEN S. KRUTZ, HITCHING A RIDE: OMNIBUS LEGISLATING IN THE U.S. CONGRESS 2 (2001)

${ }^{121}$ KRUTZ, supra note 120, at 3-4.

${ }^{122} I d$. at 4, 32-35.

${ }^{123} \mathrm{Id}$. at 2 .

${ }^{124}$ This discussion brackets the questions raised earlier about whether congressional action is necessary for international organizations to be democratically accountable.

125 See supra note 108 . The Reagan administration actively and repeatedly sought reduced funding from Congress for other international organizations - most notably, the United Nations - precisely to enhance the United States' leverage. José E. Alvarez, Legal Remedies and the United Nations'à la Carte Problem, 12 MICH. J. INT'L L. 229 (1991).
} 
Cambodia, Laos, Uganda, and Vietnam. ${ }^{126}$ Both the Senate and the Carter administration opposed these provisions, arguing that the multilateral development banks could not accept restricted funds. ${ }^{127}$ These arguments were credible because the Inter-American Development Bank had recently rejected a U.S. appropriation that included an earmark requiring that $\$ 50$ million of the $\$ 350$ million appropriation be used to promote cooperatives, credit unions, and saving-and-loan associations. ${ }^{128}$ The Inter-American bank's president, Antonio Ortiz Mena, explained that accepting the funds would "flow both against the letter and the spirit of the [Inter-American] Bank's charter." ${ }^{129}$ Likewise, World Bank President Robert McNamara argued that accepting restricted funds would violate the World Bank's charter. ${ }^{130}$

The Carter administration initially was able to head off the conflict by promising to oppose loans to the four countries that Young identified. ${ }^{131}$ Notwithstanding the negative U.S. vote, the following year the Bank's executive directors approved a \$60 million IDA loan to Vietnam for agricultural development. ${ }^{132}$ Young responded by introducing a narrower version of his previous amendment, this time restricting only IDA funds to Vietnam, arguing that the Bank's loans to Vietnam freed up funds for that government to pursue war with its neighbors. ${ }^{133}$ This revised amendment was accepted by the House and rejected by the Senate, and led to an acrimonious and emotionally charged conference negotiation. ${ }^{134}$ The argument that the restriction violated the IDA charter was certainly not dispositive in Congress; Senator Jake Garn of Utah, for example, urged his colleagues to "forget about these legal niceties. Even if we're wrong, let's do it anyway. Let's stop the killing." 135

Before the conference negotiations concluded, McNamara took several unprecedented steps to break the deadlock. Notwithstanding the requirement in the Bank's charter that the Bank interact with its member states only through their fiscal agencies, ${ }^{136} \mathrm{McNamara}$ sat down with a dozen members of Congress to explain that the restriction was not necessary because the Bank had imposed a lending freeze on Vietnam. ${ }^{137}$ When this approach did not satisfy Young and his supporters, U.S. Treasury officials did something unusual: they worked with the U.S. executive director to draft a letter from McNamara to Clarence Long, chairman of the

${ }^{126}$ Schoultz, supra note 83, at 567.

127 Bartram S. Brown, The United STATES AND THE POLITICIZATION OF THE World BANK 175 (1992).

${ }^{128}$ An Act Making Appropriations for Foreign Assistance and Related Programs, Title III, Pub. L. No. 94-11, 89 Stat. 17, 23 (1975).

${ }^{129}$ H. COMM. ON BANKING, CURRENCY \& HOUSING, INCREASED U.S. PARTICIPATION IN THE INTERAMERICAN DEVELOPMENT BANK, H.R. Rep. No. 94-541, at 17 (1975) (reprinting text of letter from Ortiz Mena to Treasury Secretary William E. Simon).

${ }^{130}$ See Letter from Robert S. McNamara, World Bank President, to W. Michael Blumenthal, Treasury Secretary (July 5, 1977), reprinted in Foreign Assistance and Related Agencies Appropriations for 1979: Hearings Before the Subcomm. on Foreign Operations and Related Agencies of the H. Comm. on Appropriations, 95th Cong. 535-36 (1978).

${ }^{131}$ Schoultz, supra note 83, at 567.

132 Sanford, supra note 53, at 50.

133 See LAVELLE, supra note 28, at 100; Schoultz, supra note 83, at 568-69.

${ }_{134}$ See John Felton, Freeze on Vietnam Loans Ends Effort to Restrict U.S. Funds for World Bank, CONG. Q., Nov. 3,1979 , at 2504 (describing conferees as "argu[ing] heatedly among themselves about who was more opposed to Vietnam, and who disliked McNamara the most").

${ }^{135} \mathrm{Id}$.

${ }^{136}$ IBRD Agreement, supra note 30, Art. III, $\$ 2$.

${ }^{137}$ BROWN, supra note 127, at 187; Schoultz, supra note 83, at 570. 
Subcommittee on Foreign Operations. ${ }^{138}$ The letter explained that "events over the past year have raised a very serious question about Vietnam's current commitment to a rational development policy. These questions were considered sufficiently fundamental to warrant a suspension of new lending to Vietnam." ${ }^{139}$ Once the letter was signed and delivered, the House-Senate conference committee agreed to recommend eliminating all restrictions on U.S. contributions to the Bank. ${ }^{140}$

The episode reveals just how powerful threats to suspend funding can be in motivating the executive branch — and the Bank — to satisfy Congress. In the end, McNamara promised even more than Representative Young could have achieved through his proposed restriction: at least for a time, the Bank would make no new loans to Vietnam using funds from any source. Whether the Bank would have made any new loans to Vietnam without Young's intervention is unclear: by one report, the Bank's other executive directors had already soured on lending additional funds to Vietnam. ${ }^{141}$ Nevertheless, the Bank's other executive directors excoriated McNamara for giving in to congressional demands. They accused him of violating the charter provisions governing interactions with member states and of politicizing the Bank (which, according to its charter, was to make decisions solely on the basis of economic considerations). ${ }^{142}$

\section{Making the Bank Environmentally Friendlier}

Congress's feat during the second half of the 1980s was even more impressive: it succeeded in making the Reagan administration —-whose attitude toward domestic environmental regulations was largely hostile-into a powerful advocate for environmental concerns at the Bank. Congress accomplished this goal by coupling specific negotiation instructions with credible threats to cut funding. Without those threats, Congress's legislated instructions would likely have failed to achieve more than symbolic victories.

Congress's efforts to reform the Bank's environmental track record were motivated by a sustained and effective campaign by a group of politically savvy nongovernmental organizations (NGOs). In early 1983, advocates from environmental groups operating in Washington, DC, began to organize a campaign to reform the Bank. ${ }^{143}$ They targeted the Bank not because it was the worst environmental actor among the multilateral development banks but because it was the best known and therefore most politically salient. ${ }^{144}$

One strategy for these NGOs was to approach the executive branch and urge it to embrace their cause. (If Congress were truly sidelined, that would have been their only option.) Before and since that particular time, individuals and interest groups have done so in an effort to influence U.S. policy toward the Bank. Recently, for example, representatives of private companies

\footnotetext{
${ }^{138}$ Felton, supra note 134 , at 3.

139 See 125 Cong. Rec. 34,414-15 (1979) (at Representative Young's request, reprinting newspaper article that quotes the text of the letter).

${ }^{140} \mathrm{Id}$.

${ }^{141} \mathrm{Id}$.

142 William Clark, Robert McNamara at the World Bank, FOREIGN AFF., Fall 1981, at 167.

${ }_{143}$ See Robert Wade, Greening the Bank: The Struggle over the Environment, 1970-1995, in 2 THE WORLD BANK, supra note 45, at 611, 658; MARGARET E. KECK \& KATHRYN SIKKINK, ACTIVISTS BEYOND BORDERS 129 (1998).

${ }^{144}$ Wade, supra note 143 , at 658-59.
} 
lobbied the executive branch to oppose loans to Argentina in order to pressure it to pay international arbitration claims. ${ }^{145}$ But the NGOs rejected that option because of the Reagan administration's antagonism to both the environmental movement and multilateral development banks. ${ }^{146}$ President Ronald Reagan came into office pressing a forceful deregulatory agenda that sought to roll back domestic environmental laws. ${ }^{147}$ The first-term Reagan administration also had no particular enthusiasm for the Bank. It negotiated lower overall levels of financial support for the Bank, with the intention that the private sector would step in as needed to provide loans to governments for large-scale development projects. ${ }^{148}$ The administration also regularly opposed Bank loans for projects that, in its view, could be financed privately. ${ }^{149}$

And so, instead of approaching the executive branch, advocates trained their attention on Congress. In 1983, as a first step, they persuaded a House subcommittee dealing with international development issues to hold two days of hearings about the Bank. ${ }^{150}$ On the first day, representatives of U.S. environmental groups described myriad ways in which the Bank was poorly equipped to evaluate and address the adverse environmental consequences of the projects supported by its loans. ${ }^{151}$ The following day's testimony focused on the ways in which Bank-supported projects had harmed indigenous populations. ${ }^{152}$ As the hearing ended, the subcommittee chairman pronounced it both "thought provoking" and "somewhat disturbing" - assessments that were shared by other members of the subcommittee-and promised further action. ${ }^{153}$

Two years later, in 1985, Congress adopted the first batch of legislated instructions targeting environmental aspects of lending by both the Bank and its regional counterparts. Most of these instructions required the secretary of the treasury to instruct the U.S. executive directors of the Bank and other multilateral development banks to secure commitments from the banks to "add or strengthen professionally trained staff to undertake environmental review of projects" and to "increase the proportion of their lending programs supporting environmentally beneficial projects." ${ }^{54}$ The legislation also included instructions that micromanaged the negotiation process: they included, for example, a requirement that the U.S. executive directors

call for, by May 31, 1986, separate and special meetings of each of the Boards of Executive Directors of these institutions to discuss their environmental performance, and ways in which this performance can be improved, including alternative projects considered and 38.

${ }^{145}$ Come and Get Me: Argentina Is Putting International Arbitration to the Test, ECONOMIST, Feb. 18, 2012, at

146 Wade, supra note 143 , at 667.

${ }_{147}$ Richard J. Lazarus, The Greening of America and the Graying of United States Environmental Law, 20 VA. ENVTL L.J. 75, 85-87 (2001).

${ }_{148}$ BABB, supra note 32 ; id. at $110-14$.

${ }^{149} \mathrm{Id}$. at $117-20$.

${ }^{150}$ BRUCE RICH, MORTGAGING THE EARTH 113 (1994); Environmental Impact of Multilateral Development Bank-Funded Projects: Hearings Before the Subcomm. on Int'l Dev. Inst. \& Fin. of the H. Comm. on Banking, Fin., \& Urban Affairs, 98th Cong. (1983).

${ }^{151}$ Environmental Impact of Multilateral Development Bank-Funded Projects, supra note 150, at 1-119.

${ }^{152} \mathrm{Id}$. at $489-535$.

${ }^{153} \mathrm{Id}$. at 522, 528, 535.

${ }^{154}$ Joint Resolution Making Further Continuing Appropriations for the Fiscal Year 1986, Pub. L. No. 99-190, $\$ 540$ (a)(1)-(4), 99 Stat. 1185, 1309-10 (1985). 
alternative configurations of projects with specific attention to environmental problems associated with the following categories of projects: large impoundments of rivers in tropical countries; penetration roads into relatively undeveloped areas;[and] agriculture and rural development projects[.] ${ }^{155}$

The next year's appropriation bill included more of the same, ${ }^{156}$ as did that of the following year. ${ }^{157}$

If the Reagan administration had wanted to neutralize the force of these instructions, it had at least two options available. The more confrontational option was to object to the instructions on constitutional grounds and decline to implement them. Another option was to comply, but only nominally, with Congress's instructions. For example, the U.S. executive director could have unenthusiastically delivered the requisite talking points to his or her Bank colleagues, confident that they would understand that the United States was not actually pushing hard on these issues.

The Reagan administration did neither. ${ }^{158}$ Instead, the Treasury Department became a vigorous advocate for environmental reform at the Bank. ${ }^{159}$ The turnaround in the Treasury Department's approach was dramatic. Bruce Rich, a leader of the NGO campaign, wrote that the director of the Treasury Department's Office of Multilateral Development Banks had begun to sound like a "radical street agitator[ ]" when talking about the Bank. ${ }^{160}$

The Reagan administration's own interests ultimately explain why it was willing not only to accept Congress's instructions on environmental reform but also to embrace its underlying policy goals. During President Reagan's second term, James Baker led the Treasury Department. His top priority was to increase the Bank's levels of structural-adjustment lending. Structural-adjustment loans are fast-disbursing loans that are conditioned on the borrowing state's implementation of specified macroeconomic policy changes. ${ }^{161}$ Baker viewed them as the solution to an increasingly urgent economic crisis, one touched off during the first term-in August 1982 - by Mexico's announcement that it was suspending payment on its international debt. ${ }^{162}$ The Treasury Department initially defined the problem as one of short-term liquidity and turned to the IMF, rather than the Bank, to resolve it. These efforts failed. Further action became more urgent as the ongoing economic crisis in Latin America and other

${ }^{155}$ Id., $\$ 540($ a)(6), 99 Stat. at 310.

${ }^{156}$ Joint Resolution Making Further Continuing Appropriations for the Fiscal Year 1987, Pub. L. No. 99-591, $\$ 539,100$ Stat. 3341, 3341-232 to 3341-236 (1986).

157 Joint Resolution Making Further Continuing Appropriations for the Fiscal Year 1988, Pub. L. No. 100-202, $\$ 537$ (a), 101 Stat. $1329,1329-161$ to $1329-64$ (1987).

${ }^{158}$ No signing statements accompanied the signing of Pub L. No. 99-190, 99 Stat. 1185 (1985) (containing provisions described supra notes 154-55 and accompanying text); Pub. L. No. 99-591, 100 Stat. 3341 (1986) (containing provisions described supra note 156 and accompanying text); Pub. L. No. 100-202, 101 Stat. 1329 (1987) (containing provisions described supra note 157 and accompanying text).

159 See generally Wade, supra note 143, at 665-72; BABB, supra note 32, at 187-91.

${ }^{160}$ RiCH, supra note 150, at 145 (1994).

${ }^{161}$ Foreign Assistance and Related Programs: Appropriations for 1987: Hearings Before a Subcomm. of the H. Comm. on Appropriations, 99th Cong. 595 (1986) (prepared statement of Treasury Secretary James A. Baker III identifying "the privatization of burdensome and inefficient public enterprises," "growth oriented tax reform," "improvement of the environment for both domestic and foreign direct investment," and "trade liberalization and the rationalization of import regimes" as desired policy changes).

${ }^{162}$ Gwin, supra note 45, at 232. 
developing countries reduced demand for U.S. exports and as U.S. banks fretted about their heavy exposure to the risk of default. ${ }^{163}$

In a speech at the joint Bank-IMF annual meeting in October 1985- two months before Congress adopted its first batch of legislated instructions regarding environmental issuesBaker unveiled a new set of proposals, which became known as the Baker Plan. ${ }^{164}$ The basic idea behind the plan was that in return for more lending from the Bank, debt-ridden developing countries would undertake structural reforms to ensure long-term growth and to pay off debts to private U.S. banks. ${ }^{165}$

But there was a catch: implementing the Baker Plan would require a general capital increase for the IBRD. A general capital increase, of course, could be achieved only if Congress was willing to supply the necessary funds. Until the Reagan administration could satisfy Congress that its concerns were being addressed and that its instructions were being followed, the administration would have a difficult time securing those funds. Senator Robert Kasten, a conservative Republican from Wisconsin, chaired the Senate Appropriations Subcommittee on Foreign Operations at the time. ${ }^{166}$ To the environmental advocates' pleasant surprise, Kasten embraced their arguments. He did not hesitate to make repeated — and credible—-threats to cut the Bank's funding ${ }^{167}$ (and thereby derail the Baker Plan).

It is worth considering whether the Treasury Department would have pursued environmental reform in the absence of Congress's threats to cut funding. As background, Baker, like other second-term Reagan appointees, was more pragmatic and less ideological than his predecessor, and Reagan's first-term domestic environmental deregulatory efforts had generated considerable political backlash. ${ }^{168}$ Moreover, one of the administration's main objections to domestic environmental regulations - the costs that they impose on domestic business— did not apply in the Bank context; the costs of making the Bank a more environmentally sensitive institution would largely be borne by the Bank and its borrowers. ${ }^{169}$ Even so, it seems unlikely that the administration would have made environmental reform a high priority in the absence of sustained pressure from Congress. In 1984, Treasury Deputy Assistant Secretary James Conrow testified that until Congress held its first set of hearings on the Bank's handling of environmental issues, he was completely unaware that any problems existed. ${ }^{170}$ In addition, the environmental reform goals were in some tension with the policy prescriptions that the administration sought to encourage through structural-adjustment loans. Such lending appealed to the Reagan administration as a mechanism to improve the environment for investment in developing

${ }^{163}$ BABB, supra note 32, at 132.

1641 DEVESH KAPUR, JOHN PRIOR LEWIS \& RICHARD WEBB, THE WORLD BANK: ITS FIRST HALF CENTURY 626-27 [hereinafter 1 THE WORLD BANK].

${ }^{165}$ Wade, supra note 143 , at 668; BABB, supra note 32, at 128-31.

166 Wade, supra note 143 , at 663.

${ }^{167} \mathrm{RICH}$, supra note 150 , at $126-46$.

${ }^{168}$ Lazarus, supra note 147 , at $85-87$.

${ }^{169}$ Cf. Wade, supra note 143, at 664 ("Leading the fight to reform the Bank's environmental performance would also earn [Senator Kasten] electoral credit from the strong environmental movement back home in Wisconsin without incurring the wrath of Wisconsin's environmentally unfriendly industries.").

${ }^{170}$ Draft Recommendations on the Multilateral Banks and the Environment: Hearing Before the Subcomm. on Int'l Dev. Inst. \& Fin. of the H. Comm. on Banking, Fin., \& Urban Affairs, 98th Cong. 11 (1984) ("In appearing before you in June 1983, I could honestly say that I was unaware of particular problems in these aspects of the [multilateral development bank] programs."). 
countries by shrinking their governments' involvement in their economies. ${ }^{171}$ By contrast, pursuing Congress's environmental goals required the Bank's international civil servants, as well as the governments in the borrowing states, not only to take on new responsibilities but to do more rather than less.

In any event, the Bank responded to persistent pressure from the United States and other member states by making a series of highly visible organizational changes. In May 1987, Bank president Barber Conable established a new department with both a significantly larger staff and more authority than its predecessor, the Office of Environmental and Scientific Affairs. ${ }^{172}$ Satisfied that these developments reflected genuine progress, Congress appropriated funds for the capital increase in 1988.

\section{The Availability of Threats to Cut Funding}

Threats to cut funding are a powerful motivator, but they are not always available. When the executive branch is itself seeking to reduce funding for an international organization, Congress gains little by threatening additional funding cuts.

Recall, for example, the instructions that Congress passed in 1977 requiring opposition to loans to countries that engaged in consistent patterns of human rights violations. ${ }^{173}$ Although Reagan administration officials indicated that they would observe the requirements of the human rights provision, ${ }^{174}$ their implementation was grudging during Reagan's first term in office. In particular, because the voting instructions required public disapproval of these states for their human rights records, they contravened the State Department's preference for "traditional" diplomacy. ${ }^{175}$ Within six months of President Reagan's inauguration, administration officials informed members of Congress that they would no longer oppose loans to Argentina, Chile, Paraguay, South Korea, or Uruguay. ${ }^{176}$

Incredulous members of Congress cited the State Department's own evidence that the frequency and gravity of human rights violations remained high, especially in Argentina. ${ }^{177}$ The administration argued that, because these countries' human rights records were improving, the statutory criterion of a "consistent pattern of gross violations of internationally recognized human rights" was no longer met—and therefore that the statute no longer required U.S. opposition. ${ }^{178}$ Some, including Senator Edward Kennedy, accused the administration of

${ }^{171}$ Statement by President Ronald Reagan upon Signing H.R. 1777, 23 WeEKLY COMP. PrES. DOC. 1547 (Dec. 28, 1987) (objecting on constitutional foreign policy grounds to provisions that require the initiation of foreign negotiations and the termination of the U.S.-Soviet Embassy Agreements, and that prohibited diplomatic contact with the Palestine Liberation Organization).

172 Philippe Le Prestre, THE WORLD BANK AND THE ENVIRONMENTAL CHALLENGE 198-201 (1989); Wade, supra note 143 , at 674-75.

${ }^{173}$ See supra note 102.

${ }^{174}$ Human Rights and U.S. Policy in the Multilateral Development Banks: Hearings Before the H. Subcomm. on Int'l Dev. Inst. \& Fin. of the H. Comm. on Banking, Fin., \& Urban Affairs, 97th Cong. 48 (1981) (statement of Ernest B. Johnston Jr., senior deputy assistant secretary of state) ("In casting our future votes . . . , we will observe statutory requirements of the International Financial Institutions Act.").

${ }^{175} \mathrm{Id}$. at 37 (statement of Walter J. Stoessel Jr., under secretary of state for political affairs), 49-50.

${ }^{176} \mathrm{Id}$. at 25 (statement of Ernest B. Johnson Jr., senior deputy assistant secretary of state).

${ }^{177} \mathrm{Id}$. at 142 (statement of Representative Jerry M. Patterson).

${ }^{178}$ Id. at 25 (statement of Ernest B. Johnston Jr., senior deputy assistant secretary of state). 
blatantly disregarding the law. ${ }^{179}$ Representative Harkin, who initially sponsored the human rights instructions, announced that he would explore cutting funds for the multilateral banks. ${ }^{180}$

But the administration itself already planned to reduce U.S. financial support for the multilateral banks - which meant that reduced funding would actually implement the executive branch's preferences instead of depriving it of something that it wanted. ${ }^{181}$ Congress then resorted to more legislation: it deleted the word "consistent" from the human rights provision, with the consequence that any pattern of human rights violations (not just a consistent one) would trigger the requirement to oppose loans. ${ }^{182}$

The Reagan administration's efforts to evade the law's requirements persisted. Testifying before a House subcommittee hearing in 1985, Assistant Secretary of State Elliott Abrams declared: "This is not a good law." 183 Over the past two years, he said, the United States had opposed some loans to Chile, but more often than not it had voted in favor of them. ${ }^{184} \mathrm{Abrams}$ pointed out that the deletion of the word "consistent" did not eliminate the need to make a judgment call about whether a "pattern of human rights violations" existed. ${ }^{185}$ Indeed, when achieving a specific human rights policy goal required voting in favor of a loan to Chile, he said that he would interpret the voting instructions to permit the favorable vote- "unless I absolutely can't." 186

By 1987, the Reagan administration was seeking support for a general capital increase at the Bank and struck a far more conciliatory tone. Testifying with Abrams before the same subcommittee, a Treasury official described extensive negotiations preceding a recent vote on another loan to Chile. He said it was the "first [case] in my memory where we have engaged in an effort to try to secure other countries' support of our efforts on the human rights issue in the development banks." 187 The desire for funding matters.

The threat of funding cuts will also be unavailable when international organizations do not require regular financial support from member states. Until the IDA was established in 1960, the Bank was such an organization. The IBRD was established in 1945 but did not get significant additional capital from its member states until $1980 .{ }^{188}$ The IBRD raised most of its funds in the private capital markets, which meant that its operations "inflicted minimal pain on taxpayers in the 'donor' countries." ${ }^{89}$ This relative financial independence made it easier

\footnotetext{
${ }^{179}$ John M. Goshko, Administration Reiterates Aim of Scuttling Carter Rights Policies, WASH. POST, July 10, 1981, at A12.

${ }^{180} \mathrm{Id}$.

${ }^{181}$ See supra note 148 and accompanying text.

${ }^{182}$ An Act Making Supplemental Appropriations for the Fiscal Year Ending September 30, 1984, Pub. L. No. 98-181, \$1004, 97 Stat. 1153, 1286 (1983).

${ }^{183}$ Human Rights and U.S. Voting Policy in the Development Banks: The Case ofChile: Hearing Before the Subcomm. on Int'l Dev. Inst. \& Fin. of the H. Comm. on Banking, Fin., \& Urban Affairs, 99th Cong. 60 (1985).

${ }^{184}$ Id. at 65 (prepared statement of Elliott Abrams).

${ }^{185} \mathrm{Id}$. at 69 .

${ }^{186} \mathrm{Id}$.

187 Current Directions for United States Policy Toward Chile: Hearing Before the Subcomm. on Int'lDev. Inst. \& Fin. of the H. Comm. on Banking, Fin., \& Urban Affairs, 100th Cong. 33 (1987).

188 The Bank's first general capital increase, in 1959, provided the Bank with more callable capital but did not require additional paid-in capital from member states. 1 THE WORLD BANK, supra note 164, at 12.

${ }^{189} \mathrm{Id}$. at 2-3.
} 
for the IBRD to avoid the attention of both voters and members of Congress. ${ }^{190}$ Between the Bank's establishment in 1945 and the IDA's establishment in 1960, Congress adopted only a few statutes regarding the IBRD, all geared towards facilitating the sale of the IBRD's securities. ${ }^{191}$

The IDA's establishment changed the dynamics between member states and the Bank's management and also paved the way for greater congressional involvement. The former has been widely acknowledged by commentators. ${ }^{192}$ The latter, however, has not. Because appropriating funds is Congress's job, the establishment of the IDA empowered Congress to use funding cuts to motivate the executive branch. And because of the shared infrastructure of the IDA and IBRD, ${ }^{193}$ Congress has been able to use its leverage concerning the IDA as a means of pursuing change not just in the IDA but also in the IBRD.

This change in dynamics did not occur immediately. More than a decade passed between the IDA's establishment and the burst of legislative activity described in part II. Why did it take so long? The relatively modest size of IDA appropriations during the 1960s is one reason. ${ }^{194}$ During the 1970s, IDA replenishments grew steadily larger before leveling off in the 1980s. The more money going to the Bank, the more attention Congress was likely to pay. And these IDA replenishments were growing at a time that Congress became increasingly assertive across a broad range of foreign policy issues. ${ }^{195}$ Finally, structural changes within Congress loosened the grip of committee chairs over legislative output and made it easier for rank-and-file members of Congress to affect the content of adopted legislation. ${ }^{196}$ Thus, the Bank's own history indicates that when international organizations are dependent on regular contributions from member states, Congress is likely to pay more attention to the organization, and the executive branch is likely to pay more attention to Congress and its policy preferences.

\section{The PRESIDENT'S CONSTITUTIONAL OBJECTIONS}

In 1988, toward the end of his first year in office, President George H. W. Bush reasserted the executive branch's constitutional authority with respect to the Bank. He issued two signing statements that contested Congress's authority to issue negotiation and voting instructions. These signing statements raised the prospect of a dramatic break from the past. Before then, presidents and executive branch officials neither acted nor spoke as if they had the constitutional authority to ignore Congress's instructions regarding the Bank. ${ }^{197}$ President Bush's

\footnotetext{
${ }^{190} \mathrm{Id}$. at 1120 .

${ }^{191}$ See An Act to Permit Investment of Fund of Insurance Companies Organized Within the District of Columbia in Obligations of the International Bank for Reconstruction and Development, Pub. L. No. 83-513, 68 Stat. 494 (1954) (permitting insurance companies organized within the District of Columbia to buy IBRD securities); An Act to Further Amend Section 5136 of the Revised Statutes, as Amended, with Respect to Underwriting and Dealing in Securities Issued by the Central Bank for Cooperatives, Pub. L. No 82-305, 66 Stat. 49 (1952); An Act to Amend the National Bank Act and the Bretton Woods Agreement Act, Pub. L. No. 81-142, 63 Stat. 298 (1949) (authorizing national banks to purchase IBRD securities).

${ }^{192}$ BABB, supra note 32, at 27; MASON \& ASHER, supra note 36, at 88.

193 See supra note 50 and accompanying text.

${ }^{194} 1$ THE WORLD BANK, supra note 164, at 1131; Schoultz, supra note 83, at 544-45.

195 See generally, e.g., FRANCK \& WEISBAND, supra note 53 (describing Congress's growing activism in the wake of the Watergate scandal and the Vietnam War).

${ }^{196}$ LAVELLE, supra note 28, at 97-98; Gwin, supra note 45, at 220.

${ }^{197}$ Cf. Barron \& Lederman, supra note 57, at 952.
} 
assertions of exclusive constitutional authority threatened to take away one of the primary tools that Congress has used to direct the executive branch — and to shape policy at the Bank. These signing statements purported to give the Treasury Department more leeway to disregard Congress's demands, thereby making it much harder for Congress to replicate its successes from the previous decade. If the president really was prepared to ignore congressional voting instructions, the conventional account would start to look more compelling.

Remarkably, however, on the ground there was no perceptible change. ${ }^{198}$ Repeated objections from the executive branch did not slow the pace of legislated negotiation instructions regarding the Bank. More significantly, the signing statements had no discernible impact on the Treasury Department's implementation of Congress's instructions: the department continued (and still continues) to diligently follow at least the letter of Congress's instructions. This on-the-ground reality may explain why these signing statements receive literally no mention in detailed accounts of lobbying Congress to achieve environmental reform at the Bank. ${ }^{199}$

Why, then, did the Treasury Department continue to implement instructions that U.S. executive directors deplored and that sometimes conflicted with executive branch policy preferences? The answer lies in the diverging interests of different component parts of the executive branch. Presidential signing statements are drafted by lawyers at the Justice Department's Office of Legal Counsel. As the "government's chief watchdog on issues that implicate presidential power," ${ }^{200}$ one of office's primary tasks is to object to perceived infringements.

Treasury Department officials, however, are far more reluctant to antagonize members of Congress over constitutional questions. ${ }^{201}$ Treasury Department officials are the ones who would face the fallout from disregarding Congress's instructions. They are the ones who would have to personally face the wrath of legislators in public hearings. Treasury Department officials are also the ones who must persuade Congress to appropriate funds for the Bank and other international financial institutions. Congressional support for any kind of foreign aid is hard to muster-and even harder when that aid is distributed by multilateral institutions. ${ }^{202}$ The coalitions that support funding for the Bank are fragile and vulnerable to defections from members on both the right and the left. ${ }^{203}$ If Treasury officials disregarded Congress's instructions,

\footnotetext{
${ }^{198}$ Signing statements asserting constitutional problems are sometimes, but not always, a prelude to the executive branch's non-enforcement of, or noncompliance with, the legislated provision. See, e.g., Curtis A. Bradley \& Eric A. Posner, Presidential Signing Statements and Executive Power, 23 CONST. COMMENT. 307, 343 (2006); U.S. GOV'T ACCOUNTABILITY OFFICE, PRESIDENTIAL SIGNING STATEMENTS ACCOMPANYING THE FISCAL YEAR 2006 APPROPRIATIONS ACTS, STUDY NO. B-308603 (2007) (reviewing nineteen provisions singled out in signing statements issued by President George W. Bush and finding that ten provisions were executed as written, six were not, and three were not triggered); John McGinnis, Constitutional Review by the Executive in Foreign Affairs and War Powers: A Consequence of Rational Choice in the Separation of Powers, 56 LAW \& CONTEMP. PROBS. 293, 310 n.81 (1993) (describing noncompliance with legislated provision regarding composition of U.S. delegation to specified international meetings).

199 See, e.g., Bowles \& Kormos, supra note 53 (discussing merits of constitutional objections to legislated instructions but not mentioning signing statements). Bruce Rich, a leader in the reform efforts, never mentions signing statements in his book. See RICH, supra note 150.

${ }^{200}$ Neal Devins \& Saikrishna Prakash, The Indefensible Duty to Defend, 112 COLUM. L. REV. 507, 545 (2012).

${ }^{201}$ See Louis Fisher, The Legislative Veto: Invalidated, It Survives, 56 LAW \& CONTEMP. PROBS. 273, 288 (1993) (describing presidents and their legal advisers as able to "indulge in confrontations with Congress" on constitutional questions, whereas executive agencies "cannot risk these types of collisions with the [congressional] committees that authorize their programs and provide funds").

${ }^{202}$ BABB, supra note 32, at 13-15.

203 See, e.g., Carol LanCaster, Foreign Aid: Diplomacy, DeVelopment, DOMestic Politics 76 (2007).
} 
securing funding for the international financial institutions could easily become impossible. As Representative David Obey put it, "For any administration to say, Well, we will accept the money, but ignore the limitations is to greatly increase the likelihood that they will not get the money." "204 The converse is also true: the Treasury Department may be more likely to secure the appropriations that it seeks for the Bank-or to secure larger appropriations - if it accepts and implements Congress's voting instructions. Given the choice between a smaller appropriation with no accompanying voting or negotiation instructions and a larger appropriation that does include voting or negotiation instructions, some Treasury officials have preferred the latter. $^{205}$

\section{Constitutional Objections Emerge}

During George H. W. Bush's term in office, Congress continued to legislate on the subject of environmental reform. Both advocates and members of Congress viewed the 1987 organizational changes at the Bank as improvements, but hardly sufficient to alleviate their concerns. ${ }^{206}$ In particular, advocates wanted the Bank to analyze the environmental impact of projects before approving loans to support them. Congress's efforts were not limited to environmental reform, however; it adopted legislated instructions on a wide range of issues. At the end of 1989 , Congress enacted two separate bills that included mandatory negotiation and voting instructions. The appropriations bill for fiscal year 1990 included instructions relating to competition with U.S. producers, ${ }^{207}$ climate change, ${ }^{208}$ terrorism, ${ }^{209}$ and loans to Panama. ${ }^{210}$ The following month, Congress adopted the International Development and Finance Act (IDFA), which likewise included numerous negotiation and voting instructions. ${ }^{211}$ The best known is the Pelosi Amendment (so named for its sponsor, Representative Nancy Pelosi). The Pelosi Amendment required executive directors of multilateral development banks to vote against any proposed loan unless an environmental impact assessment had been conducted at least 120 days before the loan came before the executive directors for a vote. ${ }^{212}$ In addition, the assessment had to be released to the executive directors, the rest of the Bank, affected groups, and local NGOs before the U.S. executive director could support the project. ${ }^{213}$

${ }^{204} 155$ CONG. REC. H7907 (daily ed. July 9, 2009).

205 Telephone interview with anonymous source familiar with U.S. participation in multilateral development banks over the years (Mar. 13, 2012).

${ }^{206}$ Wade, supra note 143, at 680; RICH, supra note 150, at 148-53.

207 An Act Making Appropriations for Foreign Operations, Export Financing, and Related Programs for the Fiscal Year Ending September 30, 1990, Pub. L. No. 101-167, \$522, 103 Stat. 1195 (1989) (codified at 22 U.S.C. $\$ 262(\mathrm{~h})$ ) (requiring the use of the voice and vote of the United States to oppose assistance by the Bank for the production or extraction of any commodity or mineral for export if the competition would injure U.S. producers).

${ }^{208} \mathrm{Id}$., $\$ 533$ (requiring vigorous promotion of programs to address global climate change by specified means, including by augmenting and expanding the professional staff of the Bank with the requisite expertise).

${ }^{209} \mathrm{Id}$., $\$ 563$ (requiring opposition to loans to countries that have been designated by the secretary of state as state sponsors of terrorism).

${ }^{210}$ Foreign Operations, Export Financing, and Related Programs Appropriations Act, 1990, Pub. L. No. $101-$ 167, $\$ 561,103$ Stat. 1195 (1989).

${ }^{211}$ International Development and Finance Act of 1989, Pub. L. No. 101-240, \$\$407(b), 501, 512, 103 Stat. $2492(1989)$.

${ }^{212} I d ., \$ 521$.

${ }^{213} \mathrm{Id}$. 
President Bush issued signing statements objecting to both the foreign appropriations bill and the IDFA. The signing statement for the appropriations bill focused on a provision unrelated to the Bank, but included a general statement asserting "serious misgivings as to the constitutionality and the wisdom of many provisions contained in the bill" and expressed an intention to "construe any constitutionally doubtful provisions in accordance with the requirements of the Constitution." ${ }^{14}$ A month later, the signing statement for the IDFA warned that "several provisions [of the IDFA] warrant careful construction to avoid constitutional concerns" and specifically cited "several sections [that] could be read to restrict executive authority to determine the position of the United States at various multilateral development banks." ${ }^{215}$ As is typical, these signing statements did not include any analysis of the constitutional issues or past practice regarding legislated negotiation instructions.

President Bush's constitutional objections had no impact on the Treasury Department's long-standing practice of implementing Congress's negotiation instructions. When Secretary of Treasury Nicholas Brady appeared before a Senate Appropriations Subcommittee the following spring, neither his testimony nor the senators' questions suggested that the Treasury Department was treating legislated negotiation or voting instructions as optional. Brady's prepared statement acknowledged Congress's instructions on various environmental issues with no hint of objection. ${ }^{216}$ In a letter describing the Treasury Department's implementation of instructions in the 1990 appropriations bill to "promote vigorously" specified policies to address climate change, Brady indicated that the Treasury Department had "already instructed the U.S. Executive Directors to implement Section 533 and are working with them to explore ways to implement these provisions in a useful manner." ${ }^{217}$ Senator Kasten praised Brady for "taking a very strong position." ${ }^{218}$ As for the Pelosi Amendment, both Brady himself and outside observers reported that the Treasury Department and the U.S. executive director pressed hard — and ultimately successfully_-for a Bank decision to both undertake and publicly release comprehensive environmental assessments. ${ }^{219}$

All things considered, the signing statements did not change the dynamic between the branches that existed during the Reagan administration. There is no indication that Congress began to doubt its constitutional authority; Congress continued to legislate negotiation and voting instructions; and individual members continued to threaten funding cuts. Senator Patrick Leahy, who chaired the Senate subcommittee hearing described above, indicated that he would be reluctant to support any contribution to the Bank the following year unless he saw dramatic improvement in the Bank's environmental track record. ${ }^{220}$ During the previous year,

\footnotetext{
${ }^{214}$ George H. W. Bush, Statement on Signing the Foreign Operations, Export Financing, and Related Programs Appropriations Act, 1990, 2 PUB. PAPERS 1573 (Nov. 21, 1989).

${ }^{215}$ George H. W. Bush, Statement on Signing the International Development and Finance Act of 1989, 25 WEEKLY COMP. PRES. DOCS. 1973 (Dec. 25, 1989).

${ }^{216}$ Foreign Operations, Export Financing, and Related Programs Appropriations for Fiscal Year 1991; Hearings on H.R. 5114 Before a Subcomm. of the S. Comm. on Appropriations, 101st Cong. 169, 180-81 (1990) [hereinafter Hearings on H.R. 5114] ("This is an area in which we have received a substantial mandate from Congress to press for wide-ranging reforms over the past several years. At last count, we had thirty-five separate legislative provisions encouraging us to promote more rapid progress toward one or another environmental objective.").

${ }^{217} \mathrm{Id}$. at 195.

${ }^{218} \mathrm{Id}$. at 193.

219 Wade, supra note 143 , at 686-87.

${ }^{220}$ Hearings on H.R. 5114, supra note 216, at 192 (statement of Senator Leahy).
} 
1989, Representative Obey, who chaired the relevant House appropriations subcommittee, had initially refused to make any funds available to the Bank. The funds were not restored until the House-Senate conference, and at the Senate's request. ${ }^{221}$ Although Obey's threat was not directly related to environmental issues, the episode sensitized the Treasury Department to the very real possibility that Congress might withhold funds. ${ }^{222}$ In 1990, President Bush was also seeking Congress's approval for participation in a new regional multilateral development bank, the European Bank for Reconstruction and Development. The need for affirmative congressional action on this related issue likely further motivated the executive branch to address Congress's concerns. During the remainder of President Bush's term, Congress continued to adopt legislation directing votes and negotiation objectives. President Bush continued to issue signing statements objecting to those provisions. ${ }^{223}$ And the Treasury Department continued to implement the legislated instructions.

This status quo largely continued during both of the following administrations. President Bill Clinton issued signing statements objecting to some legislative provisions that he perceived to interfere with his foreign affairs authority, ${ }^{224}$ including several signing statements objecting to legislated instructions regarding the Bank. ${ }^{225} \mathrm{He}$ raised objections less consistently, however, than his predecessor. President Clinton often signed, without comment, legislation that included mandatory voting or negotiation instructions. ${ }^{226}$ Whether he objected or not, the Treasury Department continued to act in accordance with Congress's instructions. ${ }^{227}$ During

${ }^{221}$ Bowles \& Kormos, supra note 53, at 793.

${ }^{222} I d$.

${ }^{223}$ George H. W. Bush, Statement on Signing the Foreign Operations, Export Financing, and Related Programs Appropriations Act, 1991, 26 WEEKLY COMP. PRES. DOCS. 1770 (Nov. 12, 1990) (expressing concern about provisions that "purport to direct, or forbid, negotiations with foreign governments or entities" and that "require the executive branch . . . to present specific positions to international organizations"). The statute includes provisions requiring the U.S. executive director to encourage greater reliance on field offices in assessing project proposals and to hold open hearings in the borrowing country during project identification and preparation. See An Act Making Appropriations for Foreign Operations, Export Financing, and Related Programs for the Fiscal Year Ending September 30, 1991, Pub. L. No. 101-513, 104 Stat. 1979 (1990).

${ }^{224}$ See, e.g., William J. Clinton, Statement on Signing the Department of Commerce, Justice, State, the Judiciary, and Related Agencies Appropriations Act, 2001, 36 WeEKLY COMP. PRES. DOCS. 3153 (Dec. 21, 2000) (objecting to provisions regarding Kyoto protocol); William J. Clinton, Statement on Signing the Holocaust Victims Redress Act, 34 WEEKLY COMP. PRES. DOCS. 263, 263 (Feb. 23, 1998) (objecting to a provision that "purports to direct the President on how to pursue negotiations with foreign states").

225 See William J. Clinton, Statement on Signing the Foreign Operations, Export Financing, and Related Programs Appropriations Act of 2001, 36 WEEKLY COMP. PRES. DOCS. 2809 (Nov. 13, 2000); William J. Clinton, Statement on Signing the Global AIDS and Tuberculosis Relief Act of 2000, 36 WEEKLY COMP. PRES. DOCS. 1906, 1907 (Aug. 28, 2000) (objecting to "provisions [that] seem to direct the Administration on how to proceed in negotiations related to the development of the World Bank AIDS Trust Fund"); William J. Clinton, Statement on Signing Consolidated Appropriations Legislation for Fiscal Year 2000, 35 WEEKLY COMP. PRES. DOCS. 2458 (Dec. 6, 1999); William J. Clinton, Statement on Signing the Omnibus Consolidated and Emergency Supplemental Appropriations Act, 1999, 34 WeEKLY COMP. PrES. DoCs. 2108 (Nov. 2, 1998); William J. Clinton, Statement on Signing the Foreign Relations Authorization Act, Fiscal Years 1994 and 1995, 30 WEEKLY COMP. PRES. DOCS. 948 (May 9, 1994).

226 See, e.g., An Act Making Appropriations for Foreign Operations, Export Financing, and Related Programs for the Fiscal Year Ending September 30, 1995, Pub. L. No. 103-306, \$\$514, 526, 108 Stat. 1608, 1633 (1994).

227 See, e.g., Foreign Operations, Export Financing, and Related Programs Appropriations for 2001: Hearings Before a Subcomm. of the H. Comm. on Appropriations, 106th Cong. 311 (2000) ("Under legislative sanctions imposed in 1998, we are required to oppose (i.e., abstain or vote 'no') any multilateral lending to India except for loans that support basic human needs. In April 2000, we abstained on one IBRD loan and one IDA credit . . . in accordance with this mandate.") (response by Treasury Secretary Lawrence H. Summers to question for the record). 
President George W. Bush's administration, the status quo persisted; the only difference was that he issued signing statements more consistently. ${ }^{228}$ By the end of his second term, Congress and the executive branch had reached a practical accommodation, if not quite a resolution, regarding their respective constitutional authority as to negotiations with the Bank.

\section{Constitutional Confrontation}

When President Obama assumed office, Congress's practice of regularly enacting negotiation instructions regarding the Bank dated back three-and-a-half decades. On paper, the president had objected to this exercise of authority for two decades. On the ground, however, the Treasury Department consistently implemented Congress's instructions. Although the Obama administration's practice reflected continuity with previous administrations, he issued a signing statement in June of 2009 that triggered a confrontation. In the end, however, the confrontation changed nothing. Congress effectively defended its claim to authority to enact mandatory negotiation and voting instructions. Although the executive branch did not explicitly concede Congress's constitutional authority, President Obama has (at least thus far) refrained from issuing additional signing statements concerning Congress's Bank instructions, and the Treasury Department has continued to act in accordance those instructions.

In his first six months in office, President Obama signed two appropriations bills that included legislated negotiation and voting instructions regarding the Bank. The 2009 Omnibus Appropriations Act included instructions regarding loans to Burma and Zimbabwe, loans for commodities or suppliers that competed with U.S. producers, and loans that imposed user charges for primary education or primary health care. ${ }^{229}$ The 2009 Supplemental Appropriations Act, adopted three months later, included instructions regarding loans to state sponsors of terrorism, the Bank's disclosure policies, and the terms of loans for extractive industries. ${ }^{230}$ In addition to these provisions, the legislation included a $\$ 100$ billion credit line for the IMF, together with instructions for the U.S. executive director of the IMF. ${ }^{231}$ The administration had specifically requested the IMF credit line after President Obama pledged to support new IMF funding to address the global financial crisis at the G-20 summit in London on April 2, 2009. President Obama issued statements objecting to these mandatory provisions in both bills and indicating that he would not treat those provisions as "limiting [his] ability to negotiate and enter into agreements with foreign nations." 232

The June 2009 signing statement provoked outrage among members of Congress for two reasons. First, lining up support for the IMF funds that the president requested had not been

\footnotetext{
228 See, e.g., George W. Bush, Statement on Signing the Consolidated Appropriations Act, 2008, 43 WeEKLY COMP. PRES. DOCS 1638 (Dec. 26, 2007); George W. Bush, Statement on Signing the Foreign Operations, Export Financing, and Related Programs Appropriations Act, 2006, 41 WeEKLY COMP. PRES. DOCS 1718 (Nov. 14, 2005); U.S. Government Accountability Office, supra note 198, at 33-34 (finding that the Treasury Department implemented voice-and-vote instructions notwithstanding constitutional objection made in signing statement).

${ }^{229}$ See Omnibus Appropriations Act, Pub. L. No. 111-8, \$\$7026, 7030(b), 7070(e), 7071(b), 123 Stat. 524 (2009).

230 See An Act Making Supplemental Appropriations for the Fiscal Year Ending September 30, 2009, Pub. L. No. 111-32, \$\$1110-12, 1404, 123 Stat. 1859 (2009).

${ }^{231}$ See id., $\$ \$ 1112(\mathrm{~d}), 1404$.

232 Barack Obama, Statement on Signing the Omnibus Appropriations Act 2009, 2009 DAILY COMP. PrES. DoC. 145 (Mar. 11, 2009); see Barack Obama, Statement on Signing the Supplemental Appropriations Act 2009, 2009 DAILY COMP. PRES. DOC. 501 (June 24, 2009).
} 
easy. Lawmakers were particularly leery of providing additional funds to the IMF after earlier efforts to rescue U.S. banks had proved politically controversial. ${ }^{233}$ The members of Congress who supported the credit line to the IMF were angry that the reward for their successful efforts was a signing statement that challenged the constitutionality of the very legislation that supplied the requested funds. Second, the signing statements surprised lawmakers who had expected a different practice from President Obama, given his criticisms, while campaigning, of his predecessor's use of signing statements. ${ }^{234}$

Members of Congress condemned the signing statement and threatened to withhold future funds. Speaking on the floor, House Financial Services Chair Barney Frank bridled:

The notion that an administration can take the money and pick and choose what it wants to do with the conditions is unacceptable. So let me say, as chairman of the committee that authorizes these [funds] and as someone who works closely with the appropriators in doing it, if the administration does not withdraw this claim that they can ignore conditions we put on it, then they will have nothing to ignore because there won't be any conditions and there won't be any money. ${ }^{235}$

The House collectively registered its fury over the signing statement by subsequently approving - by a vote of 429 to 2 - an amendment to another pending appropriations bill that would have barred any use of funds inconsistent with the provisions targeted by the president's June signing statement. ${ }^{236}$ Although the amendment was never enacted, then-Representative Mark Kirk said, "[T] he signal that we've sent to the Treasury is very clear: Ignore [the] statute at your extreme peril. And this is on behalf of a bipartisan, overwhelming majority." 237

Treasury Department officials were distraught. ${ }^{238}$ The signing statement "in effect undercut something to which the Treasury Department had agreed," and "antagonized people with [whom] Treasury would have to deal on many other matters." ${ }^{339}$ Although they were told that that the signing statement was coming, ${ }^{240}$ Treasury officials did not have a meaningful opportunity to object. Seeking to control the damage, the Treasury Department immediately reassured members of Congress that it would abide by the legislated instructions. ${ }^{241}$ Treasury Secretary Timothy Geithner repeated this assurance several months later in a question for the

${ }^{233}$ Bob Davis \& Greg Hitt, Major IMF Contribution Faces Resistance in U.S. Congress, WALL ST. J., June 10, 2009, at A6.

${ }^{234}$ See, e.g., Anne Flaherty, Democrats Irked by President's Signing Statement: Obama Criticized George W. Bush for Doing the Same, BOSTON GLOBE, July 22, 2009, at 8.

235155 CONG. REC. H7907 (daily ed. July 9, 2009); see supra note 204 and accompanying text. Representatives Frank and Obey, along with two other colleagues, sent a letter to President Obama reiterating both the complaint about the signing statement and the accompanying threat to cut funding. See Letter from Barney Frank and David Obey to President Obama (July 21, 2009), reprinted in Press Release, House Financial Services-Democrats, House Chairs Warn President of Dangers of Signing Statements (June 21, 2009), at http://democrats.financialservices. house.gov/press/PRArticle.aspx?NewsID = 515.

236 See 155 CONG. REC. H7907 (daily ed. July 9, 2009) (reproducing amendment offered by Representative Kirk on behalf of Representative Granger); id. at H7913 (recording 429-2 vote in favor).

${ }^{237}$ Id. at $\mathrm{H} 7908$ (statement of Representative Kirk).

238 Telephone interview with Edwin (Ted) Truman, former Treasury Department Assistant Secretary for International Affairs (1998-2001) and Counselor to the Secretary (2009) (Mar. 13, 2012).

${ }^{239} \mathrm{Id}$.

${ }^{240} \mathrm{Id}$.

${ }^{241}$ See id. (statement of Representative Frank) ("I've been told by Treasury they intend to abide by them."). 
record. ${ }^{242} \mathrm{~A}$ Treasury Department manual updated a year after the confrontation warned staff: "Your compliance with these provisions is vital to Treasury policy interests within the IFIs [international financial institutions]. Congressional support for U.S. participation in the IFIs is dependent in part on how well Treasury implements these provisions." ${ }^{243}$

In this instance the president himself also backed away-at least a little bit. After the confrontation over the June 2009 signing statement, the Obama administration modified its practice concerning such statements. Since that date, two separate appropriations bills have been passed that included legislated instructions regarding the Bank. ${ }^{244}$ Several of these provisions were either identical or very similar to provisions in previous bills that had elicited objections in signing statements. ${ }^{245}$ Both bills included new language directing votes on loans to Sri Lanka. ${ }^{246}$ Neither bill was the subject of a signing statement, but a White House spokesperson explained that the absence of a signing statement did not signal a change in views about the constitutionality of legislated instructions: "The administration's views about certain provisions in the omnibus spending statement had previously been publicly communicated so it wasn't necessary to duplicate them in a signing statement." 247

In the end, the Obama administration did not concede the constitutionality of the legislated negotiation and voting instructions - but it did choose to avoid additional direct confrontations with Congress. Thus, although administrations over the last two decades have reserved the option to decline to follow Congress's instructions, they have not acted on that reservation. The need to secure congressional funding has also convinced the Treasury Department that, regardless of the constitutional arguments made in signing statements, the department cannot afford to ignore Congress's negotiation instructions. Congress's threats to cut funding have consequently done more than motivate the executive branch to pursue specific policy goals. Those threats have helped Congress defend its role in instructing U.S. executive directors as to how they should go about their day-to-day interactions with the Bank.

\footnotetext{
242 See The U.S. and the G-20: Remaking the International Economic Architecture: Hearing Before the S. Comm. on Foreign Relations, 111 th Cong. 36 (2009) (responding to a question for the record, Geithner stated, "Treasury takes very seriously its responsibility to carry out the legislative mandates that apply to U.S. participation in the six [international financial institutions].").

243 DEP'T OF THE TREASURY, supra note 16, at 1.

${ }^{244}$ Consolidated Appropriations Act, 2010, Pub. L. No. 111-117, \$\$7026(c), 7030(b), 7070(i), 7071(b)(1), 7089(e),123 Stat. 3034 (2009); Consolidated Appropriations Act, 2012, Pub. L. No. 112-74, \$\$7025, 7029(b), 7042(j)(1), 7046(d)(4),125 Stat. 786 (2011).

245 Compare Omnibus Appropriations Act, 2009, Pub. L. No. 111-8, \$7026, 123 Stat. 524, with Consolidated Appropriations Act, 2010, \$7026(c), with Consolidated Appropriations Act, 2012, \$7025(c) (containing identical provisions regarding loans for commodities or minerals that compete with U.S. producers); compare Consolidated Appropriations Act, 2009, $\$ 7030$, with Consolidated Appropriations Act, 2010, $\$ 7030$ (b) (containing nearly identical language regarding loans that would require user fees or services charges on poor people for primary education or primary health care); compare Omnibus Appropriations Act, 2009, $\$ 7070(\mathrm{e})(1)$, with Consolidated Appropriations Act, 2012, \$7042(j), and Consolidated Appropriations Act, 2010, \$7070(i) (regarding loans to Zimbabwe); compare Omnibus Appropriations Act, 2009, \$7071(b), with Consolidated Appropriations Act, 2010, \$7071(b), and Consolidated Appropriations Act, 2012, \$7044(b) (regarding loans to Burma).

246 See Consolidated Appropriations Act, 2010, \$7089; Consolidated Appropriations Act, 2012, \$7046(d)(4).

${ }^{247}$ Charlie Savage, Obama Takes New Route to Opposing Parts of Laws, N.Y. TIMES, Jan. 9, 2010, at A10 (quoting White House spokesperson Ben LaBolt).
} 


\section{MONITORING AND OVERSIGHT}

To effectively influence Bank policy, Congress needs comprehensive, high-quality, and timely information about the Bank and its activities. Without it, Congress cannot make informed assessments about whether the Bank's activities are diverging from its preferences and whether new instructions to the executive branch are necessary. Congress also needs information about how the executive branch is discharging legislated instructions. This latter type of information is vital because the executive branch can thwart Congress's preferences by halfheartedly implementing Congress's legislated instructions. Threats to cut funding can provide additional motivation, but they cannot be credibly made for every single instruction that Congress enacts, especially as the number and diversity of legislated instructions have surged in recent years.

Effective monitoring is therefore essential, but it is also difficult. The readiest source of information is the executive branch itself, but the information that it provides may be self-serving or otherwise unreliable. ${ }^{248}$ And as explained below, to the extent that Congress seeks to supplement or verify information supplied by administration officials with information from the Bank, Congress faces considerable barriers unless the information that it seeks is already available to the public.

There is also the issue of cost. Collecting and processing information requires a significant investment of time, and time is in short supply for members of Congress and their staffs. The more costly it is to gather information about the activities of the Bank (and executive branch), the less likely it is that Congress will make the requisite effort. Likewise, the more difficult it is for Congress to determine whether the executive branch is complying with legislated instructions, the less inclined members will be to engage in monitoring, and the more inclined the executive branch will be to ignore congressional preferences. ${ }^{249}$

Matthew McCubbins and Thomas Schwartz famously divided congressional oversight into two categories: police patrols and fire alarms. ${ }^{250}$ Police patrols are the classic, visible, and timeconsuming forms of congressional oversight, including hearings and requirements that the executive branch submit reports. Fire alarms, by contrast, enlist outside groups to review administrative actions for consistency with congressional goals. ${ }^{251}$ Fire alarms are attractive to Congress because they reduce the cost of monitoring the executive branch. Administrative law procedures are a widely used form of fire alarm in the context of domestic regulation, but they generally do not apply in foreign policy contexts, including the interactions between the Treasury Department and the Bank. ${ }^{252}$

Given, then, that Congress has a limited toolkit, how does it attempt to monitor the Bank and the executive branch? As we will see below, while some informational asymmetries remain, especially between Congress and the executive branch, Congress has succeeded in shrinking them over time.

\footnotetext{
248 See infra notes $274-75$ and accompanying text.

249 JAMES M. LindSAY, CONGRESS AND THE POliTiCS OF U.S. FOREIGN POLICY 115 (1994).

${ }^{250}$ Mathew D. McCubbins \& Thomas Schwartz, Congressional Oversight Overlooked: Police Patrols Versus Fire Alarms, 28 AM. J. POL. SCI. 165, 168 (1984).

${ }^{251} \mathrm{Id}$. at 166.

252 Stewart, supra note 12, at 80. For an example of how administrative law procedures can be applied to an international regime, see Barr \& Miller, supra note 29, at 29-31.
} 


\section{Monitoring the Bank}

Since its establishment in 1945, the Bank has made available basic information regarding its operations to the public at large. It has, for example, published regular annual reports that disclose the identity of loan recipients and the size of the loans received. ${ }^{253}$ This information provided a sufficient basis for the kinds of instructions that Congress legislated during the 1970s, which focused primarily on the identity of borrowing states.

Congress's efforts to make the Bank's operations more environmentally sensitive during the 1980 s and 1990s demanded much more information, which was not easy to obtain. First, Congress had to learn about the environmental consequences of certain Bank projects. The projects were all located abroad, which made it harder to gather information about them. The reports drafted by the Bank for public consumption did not provide any indication of the potential environmental problems associated with the projects. ${ }^{254}$

Second, once the Bank adopted measures to elevate environmental concerns in its lending decisions, Congress needed information to determine whether those measures were effective or whether additional steps were necessary. Distinguishing cosmetic from genuine changes is not an easy task, and commentators continue to dispute the significance of various alterations to the Bank's operations. ${ }^{255}$

Finally, several provisions in the Bank's charter hinder congressional efforts to extract information about the Bank beyond what is publicly available. The charter specifies that members are to "deal with the Bank only through its Treasury, central bank, stabilization fund or other similar fiscal agency, and the Bank shall deal with members only by or through the same agencies." ${ }^{256}$ The Bank's immunities present another obstacle. Both the Bank's officials and its documents - like those of other international organizations — are protected. ${ }^{257}$ Bank officials are beyond the reach of Congress's subpoena power and are generally unavailable to testify before Congress. ${ }^{258}$ The Bank's immunities also limit Congress's ability to enlist the Congressional Research Service and Government Accountability Office to investigate and report on the Bank's operations. ${ }^{259}$ The Bank can waive these immunities, but—at least as a formal matterCongress cannot require it to do so. ${ }^{260}$

Undaunted, Congress has turned to three different tools to surmount these obstacles. First, it has pressured the executive branch to provide information that it has available to it through

253 See Schoultz, supra note 83, at 546.

${ }^{254}$ Wade, supra note 143, at 614-15 (describing shortcomings in the Bank's reporting regime before 1987 as "too weak to pick up more than egregious cases of damage, and perhaps not all of those"); see also RICH, supra note 150 , at 113 n.*.

${ }^{255}$ Compare, e.g., Nielson \& Tierney, supra note 53, with Tamar Gutner, World Bank Environmental Reform: Revisiting Lessons from Agency Theory, 59 INT'L ORG. 773, 778-79 (2005).

${ }^{256}$ IBRD Agreement, supra note 30, Art. III, \$2.

257 See 22 U.S.C. \$288(a), (d); Exec. Order No. 9751, 11 Fed. Reg. 7713 (July 11, 1946); Exec. Order No. 11966, 42 Fed. Reg. 4331 (Jan. 19, 1977).

258 There were some exceptions in the Bank's very early history: in 1948 and 1949, IBRD officials testified voluntarily before several congressional committees. Jonathan Sanford \& Margaret Goodman, Congressional Oversight and the Multilateral Development Banks, 29 INT'L ORG. 1055, 1056 n.2 (1975).

${ }^{259}$ Id. at 1060-61; see also STAFF OF S. COMM. ON FOREIGN RELATIONS, 111TH CONG., REPORT ON THE INTERNATIONAL FINANCIAL INSTITUTIONS: A CALL FOR CHANGE 18 (Comm. Print 2010) [hereinafter A CALL FOR CHANGE] (citing the Government Accountability Office's lack of access to Bank officials to complete report requested by members of Congress).

${ }^{260}$ See 22 U.S.C. $\$ 288 \mathrm{a}(\mathrm{b}), \mathrm{d}(\mathrm{b})$. 
its role in supervising the U.S. executive director. ${ }^{261}$ Second, members of Congress and their staffs have informal access to additional information about the Bank. Notwithstanding the requirement in the Bank's charter that the Bank interact only with the Treasury Department, members of Congress and their staffs are in ongoing contact with Bank officials. ${ }^{262}$ In an interview, one former Senate staffer stated: "The Bank made every effort to respond to requests and provide information - even if it was publicly unavailable."263

Third, Congress has successfully sought to increase the amount of publicly available information about the Bank. It has done so by relying on the same tools described earlier in this article: voting instructions to the executive branch and threats to cut funding. ${ }^{264}$ Responding in part to pressure from Congress and the U.S. executive director, the Bank significantly revised its information disclosure policies in the fall of $1993 .{ }^{265}$ Under the new Bank policy and procedures, more Bank documents became publicly available, including project information documents, factual technical information, final staff appraisal reports, and environmental impact assessments. Congress has continued to call for greater transparency. ${ }^{266}$ The Bank further revised its information policy in 2010, making even more documents available. ${ }^{267}$ By working to increase the amount of information that is available directly from the Bank, Congress has reduced not only the obstacle posed by the Bank's immunity. It also significantly reduced the information advantage that the executive branch has over Congress by virtue of the former's supervision of the U.S. executive director and its more regular contact with the Bank. Thus, Congress's successes at the international level have a feedback effect: they facilitate future successes in motivating the executive branch to pursue Congress's preferred policies.

Publicly available information can work like a fire alarm. It allows other parties_-including NGOs-to monitor the Bank's actions and to approach Congress when they perceive problems. In effect, public availability allows Congress to "crowdsource" the job of monitoring the Bank and reduces the resources that Congress must itself devote to gathering and processing information from the Bank. Congress also actively pressed to establish the World Bank Inspection Panel, another institution that enlists outside parties in the task of monitoring the Bank. ${ }^{268}$ The inspection panel allows individuals in borrowing countries to challenge the Bank's compliance with its own procedures and policies. It thereby reinforces the Bank's compliance with the environmental assessment requirements that the Pelosi Amendment helped bring

\footnotetext{
261 See Sanford \& Goodman, supra note 258, at 1059-61.

262 A CALL FOR CHANGE, supra note 259, at 3 (noting that Senator Lugar met personally with the head of each multilateral development bank); Bowles \& Kormos, supra note 53, at 808 n.212.

${ }^{263}$ Interview with Nilmini Gunaratne Rubin, former Senior Professional Staff Member for Senator Richard Lugar (Mar. 29, 2012).

264 See, e.g., Bowles \& Kormos, supra note 53, at 801; Wade, supra note 143, at 727; Lori Udall, The World Bank and Public Accountability, in THE STRUGGLE FOR ACCOUNTABILITY: THE WORLD BANK, NGOS, AND GRASSROOTS MOVEMENTS 403 (Jonathan A. Fox \& L. David Brown eds., 1998).

265 Ibrahim F.I SHIHATA, THE WORLD BANK INSPECTION PANEL 22-23 (2d ed. 2000).

266 See A CALL FOR CHANGE, supra note 259.

${ }^{267}$ See World Bank, News and Broadcast, World Bank Broadens Public Access to Information (July 1, 2010), at http://go.worldbank.org/L3HF51WOX0.

268 See IBRD Resolution 93-10 (1993); IDA Resolution 93-6 (1993); see also Bowles \& Kormos, supra note 53, at 801-07 (describing legislated instructions and threats to cut funding, specifically in relation to the establishment of the Inspection Panel).
} 
about. ${ }^{269}$ Both the Bank's evolving transparency policies and the establishment of the inspection panel have reduced Congress's informational disadvantages and empowered it to play a more active role in setting policy regarding the Bank.

\section{Monitoring the Executive Branch}

In the absence of administrative law procedures for monitoring the executive branch's interactions with the Bank, Congress has two classic "police patrol" oversight tools at its disposal: hearings and reporting requirements. Since the Bank's establishment in 1945, Congress has relied heavily on both. Congress holds regular hearings at which Treasury Department officials have testified about U.S. actions and policies regarding the Bank. ${ }^{270}$ One commentator observed that as the volume of legislation regarding the Bank increased over time, so, too, did the rank of the testifying Treasury official: by the end of the 1970s, the Treasury secretary himself was testifying. ${ }^{271}$

Reporting requirements also date back to the very beginning of the Bank's history. In 1945, Congress required the executive branch to provide periodic reports on the United States' participation in the IBRD and the IMF. ${ }^{272}$ More recently, reporting requirements on specific topics have proliferated. ${ }^{273}$ Hearings and reporting requirements may work well for policing compliance with the letter of Congress's instructions, but Congress's biggest challenge is to motivate the executive branch to do more than that. The Treasury Department's reports, for example, may not be especially helpful in Congress's effort to determine whether the executive branch merely went through the motions; the department has an incentive to present information in a way that reflects favorably upon it. ${ }^{274}$ In particular, the Treasury Department may be tempted to overstate the obstacles that it encounters in efforts to persuade other executive directors or the Bank's management to shift their positions. Congress is hard-pressed to know whether the Treasury Department and the U.S. executive director made only halfhearted efforts or whether they encountered genuinely unmovable opposition. ${ }^{275}$ Congress lacks access to independent information about the substance and intensity of other member states' preferences.

\footnotetext{
269 See generally Boisson de Chazournes, supra note 15, at 292; Nielson \& Tierney, supra note 53 (describing Inspection Panel as an example of fire-alarm oversight).

${ }^{270}$ Congressional hearings, like threats to cut funding, are not subject to the collective action problems that beset legislating. Bradley \& Morrison, supra note 8, at 446.

${ }^{271}$ BABB, supra note 32, at 69.

272 BWAA, supra note 37, $\$ 4(\mathrm{~b})(5),(6)$.

273 See, e.g., 22 U.S.C. $\$ 262 \mathrm{r}-6$ (2006) (requiring annual reports on actions that borrowing countries have taken to strengthen governance and reduce bribery and corruption).

${ }^{274}$ D. RODERICK KIEWIET \& MATHEW D. MCCubbins, THE LOGIC OF DELEGATION 31-32 (1991) ("The agent has incentives to shade things . . or to reveal information in some other strategic manner. . . Even if agents can somehow be constrained to be truthful in their reports, the principal will still not know what they are not reporting.").

${ }^{275}$ Darren G. Hawkins, David A. Lake, Daniel L. Nielson \& Michael J. Tierney, Delegation Under Anarchy: States, International Organizations, and Principal-Agent Theory, in DELEGATION AND AGENCY IN INTERNATiOnAl Organizations (Darren G. Hawkins, David A. Lake, Daniel L. Nielson \& Michael J. Tierney eds., 2006) ("If the principal observes an unsatisfactory outcome, it cannot tell for sure whether this was the result of slack by the agent, in which case the latter should be sanctioned, or some unfortunate event that disrupted the best efforts of a sincere agent, who should not be punished.").
} 
One solution is more intense monitoring. When Congress pays sustained attention to a single issue or instruction over time, the executive branch will feel more pressure to demonstrate responsiveness to Congress's instructions and to demonstrate the efficacy of its efforts in shifting Bank policy. Congress can also enlist its own staff or the Government Accountability Office to undertake more extensive evaluations of the executive branch's compliance with its instructions. ${ }^{276}$ These reports typically rely on a range of sources outside the Treasury Department, including other agencies, NGOs, and sometimes the Bank itself, and can thus provide a fuller picture of the force and effectiveness of the executive branch's efforts. ${ }^{277}$

Congress has also undertaken, at least indirectly, to enlist actors outside the government to help it police the executive branch. For example, by requiring the Treasury Department to make certain kinds of information accessible on its website, ${ }^{278}$ Congress has facilitated both police-patrol oversight (because members of Congress can review that information) and firealarm oversight (because the posted information will be easily accessible to the broader public and organized private interest groups that may, in turn, flag problems for members of Congress).

Information from the Bank itself can also strengthen Congress's hand by reinforcing its capacity to police the executive branch. Among other things, the 2010 revisions to the Bank's information disclosure policy make minutes of the executive directors' board meetings available shortly after the conclusion of the relevant meeting. ${ }^{279}$ The availability of comprehensive information from the Bank should make it easier for members of Congress and interested outside groups to verify the executive branch's accounts of its implementation of Congress's instructions. The Bank's enhanced transparency policy also puts Congress, as well as outside groups, in a better position to evaluate the extent to which their preferences are being translated into policy.

\section{GENERALIZABILITY}

In sum, the claim that international organizations undermine democracy by undermining legislatures has no empirical foundation in relation to Congress and the Bank. But how likely

\footnotetext{
276 See, e.g., U.S. GOV'T ACCOUNTABILITY OFFICE, INTERNATIONAL ENVIRONMENTAL OVERSIGHT: U.S. AGENCIES FOLLOW CERTAIN PROCEDURES REQUIRED BY LAW, BUT HAVE LIMITED IMPACT (2008); U.S. GEN. ACCOUNTING OFFICE, MORE EFFECTIVE UNITED STATES PARTICIPATION NEEDED IN WORLD BANK AND INTERNATIONAL DEVELOPMENT ASSOCIATION, REP. B-161470 (1973); A CALl FOR CHANGE, supra note 259; 1977 STAFF REPORT, supra note 82.

277 See, e.g., INTERNATIONAL ENVIRONMENTAL OVERSIGHT, supra note 276, at 25-26 (describing sources).

${ }^{278}$ Consolidated Appropriations Act, 2004, Pub. L. No. 108-199, \$581, 118 Stat. 3, 202-04 (2004) (codified at 22 U.S.C. \$262o-3) (requiring online posting of all negative votes and abstentions made by U.S. executive directors at any multilateral development institution); Foreign Operations, Export Financing, and Related Appropriations Act, Pub. L. No. 109-102, \$599B, 119 Stat. 2172, 2241-43 (2005) (codified at 22 U.S.C. \$262o-4(e)) (requiring online posting of explanations of U.S. positions on proposals that would have a significant effect on the environment).

279 World Bank, The World Bank Policy on Access to Information, para. 23 (July 1, 2010), at http://go.world bank.org/L3HF51 WOX0. Verbatim transcripts of board meetings, as well as statements of executive directors and staff in the context of board meetings, remain unavailable to the public under the new policy for a period of ten years. Id., para. 33 .
} 
is Congress to be able to achieve similar results with other international organizations? ${ }^{280}$ As the Bank example demonstrates, Congress's efficacy in influencing an international organization depends both on domestic political dynamics and on features of the international organization itself. In considering whether the Bank example is typical, it is helpful to break out three distinct questions. Are there features of the Bank that make Congress especially motivated to become involved in Bank policy? Do these features facilitate Congress's ability to persuade the executive branch to adopt Congress's policy preferences or to follow its negotiation and voting instructions? And finally, are there unique features of the Bank that improve the likelihood that Congress will succeed in securing adoption of its preferred policies at the international level?

This part of the article considers and ultimately rejects several possible reasons why the Bank may be unique (or close to it) in ways that facilitate Congress's involvement or amplify its influence. First, one might think that Congress is unusually motivated to become involved in shaping Bank policy because of the subject matter of the Bank's operations. Second, perhaps Congress is especially likely to become involved, and the executive branch is especially solicitous of Congress's preferences, because U.S. participation in the Bank was authorized by congressional-executive agreement. Finally, perhaps the Bank is atypical because of the United States' disproportionate degree of influence there. It turns out, however, that each of these attributes is either incidental to Congress's successes regarding the Bank or widely shared among international organizations in which the United States participates; if the Bank example is unrepresentative, it must be for other reasons.

This part closes with a brief comparison of the Bank and the IMF that suggests one limit on the generalizability of the Bank example: Congress's ability to influence the Bank is unlikely to be replicable with organizations that do not require regular funding. Because such organizations are rare, however, this limitation is not a significant one.

\section{Subject Matter and Congressional Motivation}

Perhaps the Bank is a special case, and Congress is unusually motivated to become involved in policymaking regarding the Bank because of the subject matter with which it deals. The Bank's activities significantly overlap with Congress's constitutional authority. ${ }^{281}$ Congress appropriates and directs foreign aid, and establishes and directs U.S. agencies (for example, the Export-Import Bank and the U.S. Agency for International Development) that, like the Bank, provide grants and loans to foreign governments. Legislation on foreign aid reflects substantive policy choices. ${ }^{282}$ Focusing attention on the Bank could be appealing, especially for members of Congress looking to gain support from particular interest groups or to bolster their reputations in the foreign relations field (perhaps with an eye toward seeking higher office). ${ }^{283}$

\footnotetext{
${ }^{280}$ A related question (one that is beyond the scope of this article) is whether legislatures in other member states can replicate Congress's success. To the extent that Congress is aided by the United States' disproportionate influence over the Bank, Congress's successes may be difficult for other legislatures to replicate.

${ }^{281}$ See supra note 74 and accompanying text (discussing Congress's constitutional authority relevant to the Bank's work).

282 See generally LANCASTER, supra note 203, at 62-109 (describing shifts in congressional approaches to foreign aid policy over time).

${ }^{283}$ LINDSAY, supra note 249 , at $40-43$.
} 
There is good reason to believe, however, that other international organizations would be even more likely than the Bank to motivate congressional action. Members of Congress are most likely to become interested in international organizations if their constituents are. ${ }^{284}$ And their constituents are most likely to become interested in those international organizations that directly impose costs or confer benefits on them. ${ }^{285}$ Along this crucial dimension, the Bankcompared to other organizations-is likely to be unworthy of members' time and attention. The primary cost that the Bank imposes on the United States is the opportunity cost: the money that Congress appropriates for the Bank could be spent elsewhere. ${ }^{286}$ Other international organizations promise (or threaten) more significant benefits or costs than does the Bank. Among international financial institutions, for example, the IMF's decisions can confer significant benefits on U.S. financial institutions. For that reason, banks specializing in wholesale and international banking-typically located in major financial centers such as Chicago, New York, and San Francisco- engage in extensive lobbying efforts regarding the IMF. ${ }^{287}$ The Montreal Protocol requires that parties phase out the consumption and production of specified ozone-depleting substances; the parties' decisions about how quickly those substances are phased out can both impose costs on users of those substances and generate benefits for businesses that manufacture alternative substances. Participation in the World Trade Organization (WTO) requires dismantling protectionist measures and thereby benefits those businesses that rely on imports or that are seeking to export their products, while imposing sometimes substantial costs on those businesses that face increased competition from abroad. The Bank's ability to attract Congress's attention is hardly unique.

\section{Approval by Congressional-Executive Agreement}

Another possibility is that the Bank is atypical among international organizations because Congress authorized U.S. participation in the Bank by congressional-executive agreement. On this hypothesis, approval by congressional-executive agreement made Congress more likely to become involved in the Bank over time and also made the executive branch more accepting of a significant congressional role in shaping Bank policy. The Bank's early history suggests there may be something to this: as discussed in part II, the executive branch's eagerness to secure authorization for U.S. participation in the IBRD and IMF by congressional-executive agreement may explain the executive branch's failure to object to the negotiation instructions included in that agreement.

There is no indication, however, that Congress's approval by congressional-executive agreement in 1945 influenced subsequent actions or reactions of either Congress or the executive branch. None of the later discussions about the constitutionality or desirability of Congress's negotiation instructions referenced either Congress's initial role in approving participation in the Bank or the inclusion of negotiation instructions in the Bretton Woods Agreements Act.

\footnotetext{
${ }^{284}$ Victoria Nourse, Misunderstanding Congress: Statutory Interpretation, the Supermajoritarian Difficulty, and the Separation of Powers, 99 GEO. L.J. 1119, 1125 (2011) ("There is nary a political scientist who does not believe that the electoral connection - whether viewed as a rosy aim to further the public good or a craven attempt to extract interest-group rents-is Congress's most distinctive feature.").

${ }^{285}$ Moe \& Howell, supra note 5, at 147.

${ }^{286}$ Bradley \& Kelley, supra note 15, at 16.

${ }^{287}$ See J. Lawrence Broz \& Michael Brewster Hawes, US Domestic Politics and International Monetary Fund Policy, in DELEGATION AND AGENCY IN INTERNATIONAL ORGANIZATIONS, supra note 275, at 77, 77 n.2.
} 
During the recent row over President Obama's signing statement, members of Congress linked the appropriateness of the negotiation instructions to Congress's role in funding the Bank's operations, ${ }^{288}$ but Congress would retain the authority to appropriate funds for the Bank even if the Bank's charter had been approved as an Article II treaty.

Even upon the assumption that approval by congressional-executive agreement did matter, nothing distinguishes the Bank, in this context, from other international organizations for which such agreements were used. Majorities in both houses of Congress, rather than twothirds of the Senate, have authorized U.S. participation in many other trade and financial organizations. ${ }^{289}$ Although the UN Charter was approved as an Article II treaty, the record for the specialized agencies is split. Participation in the Food and Agriculture Organization, the UN Educational, Scientific and Cultural Organization, and the World Health Organization was approved by congressional-executive agreement. Participation in the International Atomic Energy Agency, the International Civil Aviation Organization, and the World Intellectual Property Organization was approved by Article II treaty. The record on international organizations dedicated to particular commodities is likewise split. ${ }^{290}$ The explanation for this pattern of approval is uncertain, ${ }^{291}$ and it is not all obvious why members of Congress (or their constituents) would be systematically more motivated to shape policy in international organizations that were approved by congressional-executive agreement.

What is more, Congress often plays a significant role in implementing Article II treaties, as when it adopts implementing legislation after the Senate's consent to ratification. ${ }^{292}$ Implementing legislation gives both chambers of Congress the opportunity to influence the United States' participation in the new international organization. It may also carve out an ongoing role for Congress and facilitate its ability to keep close tabs on the executive branch. For example, the United States joined the International Coffee Organization in 1963 after the Senate consented to ratification of the International Coffee Agreement. ${ }^{293}$ The Agreement was designed to control coffee prices through a system of export quotas. ${ }^{294}$ Congress doled out implementing authority to the executive branch in remarkably short, time-limited increments. The initial implementing legislation, adopted in May 1965, provided import and export

${ }^{288}$ See subsection "Constitutional Confrontation" in part IV, above.

289 This process has been followed for the other organizations that make up the World Bank Group as well as for the IMF, regional development banks, the WTO, and commissions established by the North American Free Trade Agreement, including the Commission for Environmental Cooperation and the Commission for Labor Cooperation.

${ }^{290}$ For example, compare the International Cotton Institute (participation approved by legislation) with the International Coffee Organization (participation approved by two-thirds of the Senate).

${ }^{291}$ Cf. Hathaway, supra note 13 (making this same point regarding the pattern for international agreements generally, not just those that create international organizations).

292 See, e.g., Chemical Weapons Convention Implementation Act of 1998, Pub. L. No. 105-277, 112 Stat. 2681-856 (following Senate consent to ratification of the Convention on the Prohibition of the Development, Production, Stockpiling and Use of Chemical Weapons and on Their Destruction, opened for signature Jan. 13, 1993, S. TREATY DOC. No. 103-21); Great Lakes Fishery Act of 1956, Pub. L. No. 557, 70 Stat. 242 (following Senate consent to ratification of the Convention on Great Lakes Fisheries, U.S.-Can., Sept. 10, 1954, 6 UST 2836); International Atomic Energy Agency Participation Act of 1957, Pub. L. 85-177, 71 Stat. 453 (following Senate consent to ratification of the Statute of the International Atomic Energy Agency, Oct. 26, 1956, 8 UST 1093, 276 UNTS 3).

${ }^{293}$ International Coffee Agreement, Aug. 28, 1957, Pub. L. 85-177, 14 UST 1911.

${ }^{294}$ See generally ROBERT H. BATES, OPEN-ECONOMY POLITICS: THE POlitiCAL ECONOMY of THE WORLD COFFEE TRADE 125-27 (1997). 
authority for a three-year period. ${ }^{295}$ In 1968 , Congress extended this authority for a two-year period, until 1970. ${ }^{296}$ The next two authorizations each lasted for less than a year. ${ }^{297}$

In the end, then, the method for approving U.S. participation does not appear to correlate with Congress's level of interest or to predict whether Congress's efforts to shape policy regarding that organization will be effective.

\section{The United States' Disproportionate Influence}

The United States' influence over the Bank may exceed that of other member states for a number of reasons. Not only is the United States the Bank's largest funder, but its vote is weighted to reflect its financial contributions. The Bank president has historically always been an American, and the Bank is located in Washington, DC, within a few miles of both the United States Capitol and the White House. But are these sources of the United States' disproportionate influence unique to the Bank? Are they critical to Congress's successes with respect to the Bank?

Share of funding. The United States commonly supplies a large share of funding for international organizations and is frequently the member state that contributes the most. The share of funds that the U.S. provides to the Bank (15 percent as of March 2013) is in the range of what the United States contributes to other international organizations in which it participates. ${ }^{298}$ The United States supplies 22 percent of the United Nations' regular budget, and 27 percent of the United Nations' peacekeeping budget. ${ }^{299}$ The World Health Organization's scale of assessments tracks that of the United Nations' regular budget; the United States supplies 22 percent. ${ }^{300}$ The United States pays a smaller share of the WTO's budget, about 12 percent, but it remains the largest contributor. ${ }^{301}$ For regional organizations, the United States' share is often much higher. The United States supplies 33 percent of member state contributions to the Inter-American Tropical Tuna Commission, and more than half of the member state contributions to the Organization of American States. ${ }^{302}$ As part III explains, the size of the U.S. funding share may well affect the Bank's willingness to heed Congress's concerns. But the Bank is hardly unusual in receiving a significant share of its funds from the United States.

${ }^{295}$ International Coffee Agreement Act of 1965, Pub. L. No. 89-23, \$2, 79 Stat. 112 (1965).

${ }^{296}$ Renegotiation Amendments Act of 1968, Pub. L. No. 90-634, \$302, 82 Stat. 1345 (1968).

297 Coffee Agreement Act of 1968, Continuation, Pub. L. No. 91-694, \$3, 84 Stat. 2077 (1971); An Act to Continue Until the Close of September 30, 1973, the International Coffee Agreement Act of 1968, Pub. L. No. 92-262, 86 Stat. 113 (1972)

298 See supra note 41.

${ }^{299}$ GA Res. 64/248 (Feb. 5, 2010); Report of the Secretary-General, Implementation of General Assembly Resolutions 55/235 and 55/236, UN Doc. A/64/220 (Sept. 23, 2009); BASIC FACTS ABOUT THE UNITED NATIONS $28-29$ (2011).

${ }^{300}$ World Health Assembly, Scale of Assessments for 2012-2013 (May 24, 2011), at http://apps.who.int/gb/ ebwha/pdf_files/WHA64/A64_R21-en.pdf.

${ }^{301}$ World Trade Organization, Members' Contributions to the WTO Budget and the Budget of the Appellate Body for the Year 2011, at http://www.wto.org/english/thewto_e/secre_e/contrib11_e.htm.

302 Organization of American States, Program-Budget of the Organization 2012, Annex II, tbl.A, at http://www. oas.org/consejo/sp/CAAP/docs/Approved\%20Program\%20Budget\%202012\%20ENG\%20_\%20No\%20posts. pdf; 2008 Annual Report of the Inter-American Tropical Tuna Commission, App. 2, at http://www.iattc.org/ PDFFiles2/AnnualReports/IATTC-Annual-Report-2008.pdf. 
Weighted vote. International organizations that weight member states' votes by their financial contributions are limited to international financial institutions, although other international organizations give the United States a larger role in decision making in other ways. The most prominent is the UN Security Council, where a resolution can be vetoed by the United States or any of the Council's four other permanent members. ${ }^{303}$ Other international organizations virtually guarantee the United States a slot on specialized organs comprising a subset of member states. For example, the Executive Council of the International Civil Aviation Organization comprises thirty-six states, including "States of chief importance in air transport." 304 The Governing Body of the International Labour Organization likewise guarantees a set number of slots for "member states of chief industrial importance." 305

In any event, the Bank case study does not support the proposition that the United States' weighted vote at the Bank made Congress more influential than it would have been in an organization that operated on a one-state, one-vote basis. As parts II and III explain, even after Congress started legislating voting instructions, its influence remained symbolic until it found other ways to motivate the executive branch. The United States' weighted vote is incidental to Congress's success in influencing the Bank.

Nationality of president. When it comes to the nationality of international organizations' top officials, a handful of organizations share the Bank's tradition. Executive directors of UNICEF have consistently been U.S. nationals, as have directors-general of the International Organization for Migration. ${ }^{306}$ In many international organizations with non-U.S. nationals at the helm, there is a strong tradition of U.S. nationals one level down. For example, U.S. nationals are consistently appointed to be first deputy managing director at the IMF, under-secretarygeneral at the United Nations, deputy director-general at the Food and Agriculture Organization, deputy director-general at the WTO, and deputy secretary-general at the Organisation for Economic Co-operation and Development. ${ }^{307}$ If having U.S. nationals at the highest levels improves Congress's ability to influence international organizations, a great many international organizations share that feature.

Location of headquarters. Various major international organizations, in addition to the Bank, have their headquarters in Washington, DC, including the Organization of American States and the IMF. Others, including the United Nations and some fisheries organizations, are located elsewhere within the United States. The majority are located abroad. It is hard to see how geographic location affects Congress's motivation to influence an international organization or the likelihood that Congress will see its preferred policies embraced by the executive branch or adopted by any particular organization. That said, an international organization's location in the District of Columbia might affect domestic political dynamics by making the organization more salient or by facilitating Congress's ability to monitor it. For example, informal meetings can be arranged more easily (and cheaply) when they involve travel by taxi rather

\footnotetext{
${ }^{303}$ UN Charter, Arts. 27, 108; IBRD Agreement, supra note 30, Art. VIII. The United States also has the capacity to veto individual loans made by the Inter-American Bank's Fund for Special Operations, which, like the IDA, extends concessional loans on below-market terms. Agreement Establishing the Inter-American Development Bank, Art. IV, \$\$1, 9, Apr. 8, 1959, 10 UST 3029, 389 UNTS 69.

${ }^{304}$ Convention on International Civil Aviation, Art. 50, Dec. 7, 1944, 61 Stat. 1180, 15 UNTS 295.

${ }^{305}$ Constitution of the International Labour Organization, Art. 7, June 28, 1919, 49 Stat. 2712, TS No. 874.

${ }^{306}$ Cogan, supra note 45, at 257, 261.

${ }^{307} \mathrm{Id}$. at $257-62$.
} 
than by airplane. Even so, these effects are likely to be marginal. And as international organizations adopt increasingly robust transparency measures and make more information about themselves available online, ${ }^{308}$ the difference between Congress's ability to monitor an in-town organization versus one headquartered abroad will continue to shrink.

In sum, the United States is an especially influential member of the Bank. The bases of this influence are widely shared among international organizations or incidental to Congress's successes in shaping Bank policy. They do not suggest significant limits on the generalizability of the Bank example.

\section{Comparing the World Bank and the IMF}

This subsection briefly reviews Congress's efforts to influence the International Monetary Fund, and highlights that an international organization's need for regular appropriations is central in facilitating congressional influence. The IMF tracks the Bank along all of the dimensions discussed in this subsection except funding. The IMF is, like the bank, a prominent international financial institution. U.S. participation was authorized by congressional-executive agreement (in fact, the same legislation that authorized U.S. participation in the IBRD). Among the IMF's member states, the United States contributes the largest share of funds, and its vote is weighted accordingly (16.75 percent of total votes). ${ }^{309}$ Although the IMF's managing director is traditionally a European national, its second-in-command is traditionally an American. ${ }^{310}$ Finally, the IMF is headquartered a stone's throw away from the Bank.

As noted above, the IMF's decisions can directly and significantly affect the bottom line of banks located in the United States. The volume of legislation that Congress has adopted regarding the IMF suggests that Congress is quite interested in the institution. Over the years, Congress has adopted a wide range of legislative provisions that require the U.S. executive director of the IMF to use his or her "voice and vote" to achieve (or oppose) a particular end. ${ }^{311}$ For example, Congress has directed the secretary of the treasury to instruct the U.S. executive director for the IMF to use his or her "voice and vote" to structure IMF programs and assistance "so that the maintenance and improvement of core labor standards are routinely incorporated as an integral goal in the policy dialogue with recipient countries." 312 Congress has also required the U.S. executive director to promote IMF policies that would "facilitat[e] the development and implementation of internationally acceptable domestic bankruptcy laws and regulations in developing countries." 313 And yet, one recent study suggested that when it comes to implementing these instructions, "the U.S. executive director is far from a perfect agent of Congress." ${ }^{14}$

\footnotetext{
${ }^{308}$ Benedict Kingsbury, Nico Kirsch \& Richard B. Stewart, The Emergence of Global Administrative Law, 68 L. \& CONTEMP. PROBS. 15, 38-39 (2005).

${ }^{309}$ International Monetary Fund, IMFMembers' Quotas and Voting Power, and IMF Board of Governors, at http:// www.imf.org/external/np/sec/memdir/members.aspx.

${ }^{310}$ Cogan, supra note 45.

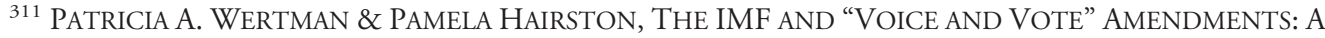
COMPILATION (Congressional Research Service, Library of Congress, 1998); U.S. DEP’T OF TREASURY, supra note 16.

31222 U.S.C. $\$ 2620-2(a)(9)(2006)$.

31322 U.S.C. $\$ 2620-2(a)(4)(2006)$.

${ }^{314}$ Broz \& Hawes, supra note 287, at 103.
} 
While a more comprehensive study is needed to confirm this observation, this article's analysis of the Bank offers reasons to believe that Congress's efforts to influence the IMF would be less effective. Like the Bank in its original incarnation-when it consisted of only the IBRD_the IMF does not require regular infusions of funds from its member states. As a consequence, the IMF can escape Congress's attention for years at a time. Congressional action is needed only sporadically - when the IMF needs to increase its lending capacity. At these discrete points in time, Congress has substantial leverage since these increases tend to be large and are typically responses to urgent international financial crises. But once a crisis is over, Congress's attention is likely to lapse; it is unlikely to engage in sustained monitoring to determine how its instructions are implemented. The absence of a need for regular appropriations also means that Congress lacks the option of cutting off funds should the performance of the IMF or of the executive branch's performance there prove lackluster. Finally, the IMF's operations are less transparent than the Bank's, ${ }^{315}$ which makes it more difficult for members of Congress to hold informed views about IMF operations and to police the effectiveness of any reforms undertaken by the IMF in the wake of congressional action. Despite the strong reasons for congressional interest in the actions of the IMF, this article suggests that Congress faces significant challenges in shaping the executive branch's interactions with the institution on an ongoing basis.

More broadly, the IMF example reaffirms the importance of an international organization's need for regular funding. Specifically, Congress may have difficulty in influencing international organizations that do not require regular funding, even if they address matters that are salient to members of Congress, participation in the organization was approved by congressional-executive agreement, and the United States exerts disproportionate influence over the organization. Because it is the rare international organization that does not require regular contributions by its member states, ${ }^{316}$ however, this key source of leverage will usually be available to Congress.

\section{CONCLUSION}

Since the early 1970s, Congress has established itself as a key player in setting U.S. policy toward the Bank. Congress does more than put the brakes on executive branch policies with which it disagrees; it affirmatively shapes the policies that the executive branch pursues. Notwithstanding its constitutional objections, the executive branch has consistently implemented at least the letter of Congress's voting and negotiation instructions. While desultory implementation of Congress's legislated instructions remains the most significant threat to their effectiveness, Congress has developed a toolkit that allows it to galvanize executive action. When it comes to the Bank, Congress has not been sidelined.

Yet the exercise of this influence has not been costless. Threats to cut funding-Congress's most effective tool for motivating the executive branch-have sometimes harmed the Bank. The persistent uncertainty with respect to the size and timing of the United States' contributions has required the Bank's senior management to devote considerable time to securing bridge financing - time that might otherwise have been devoted to actually running the

315 David Gartner, Uncovering Bretton Woods, 44 GEO. WASH. INT'L L. REV. (forthcoming).

${ }^{316}$ ALVAREZ, supra note 3, at 10. 
Bank. ${ }^{317}$ In addition, Congress's actions have led the Bank's other member states, as well as its management and staff, to complain bitterly about U.S. actions that have unnecessarily polarized and politicized the Bank's work and undermined its international character. ${ }^{318}$ The perception that the Bank is unduly catering to the United States makes other states less willing to support the Bank and to channel development assistance through it rather than through other institutions. ${ }^{319}$

Some scholars have argued that catering to the United States is exactly what is needed to avoid a democratic deficit. ${ }^{320}$ On this theory, the relevant baseline for evaluating the democratic accountability of international organizations is the level of control that domestic political actors have over purely domestic policy, with the consequence that a democratic deficit will exist unless a state can unilaterally determine outcomes at an international organization. ${ }^{321} \mathrm{But}$ when states establish an international organization, they by definition share authority to determine outcomes. ${ }^{322}$ A conception of democratic accountability that depends on a state's ability to singlehandedly determine outcomes at an international organization is literally impossible for multiple member states to satisfy simultaneously.

What is needed, instead, is a notion of democratic accountability that realistically reflects the fundamental fact that individual states cannot control international organizations in the same way that they control their domestic institutions. One possibility is to shift the inquiry from control over outcomes to control over the positions that each state's representatives take at international organizations. Are those positions formulated in a democratically accountable way? In relation to the Bank, one might ask, for example, whether the positions staked out by the Treasury Department and U.S. executive director reflect the will of the American people. As this article demonstrates, the answer is complicated; even a very large quantum of congressional activity does not ensure that this standard is met. Although the Bank has a prominent profile among international organizations, it is a subject of consistently low salience for the American public. Neither the president's election nor the election of individual members of Congress turns on the candidate's views regarding the Bank.

Nevertheless, as a consequence of Congress's ability to shape Bank policy, individual citizens or, more realistically, organized groups that become interested in the Bank's work have more than one channel available through which they can try to influence Bank policy. They can generate public debate, force the executive branch to publicly defend the positions that it takes, and potentially shift U.S. policy. When members of Congress embrace a particular view about what the Bank should or should not be doing, they have powerful tools at their disposal to translate those views into U.S. policy. Congress's ability to do so has been both overlooked and undervalued. When it comes to influencing international organizations, Congress is not feckless. Congress has more tools, and deploys them much more regularly and successfully, than the conventional wisdom on foreign affairs suggests.

\footnotetext{
317 Gwin, supra note 45, at 269.

318 See, e.g., LAVELLE, supra note 28, at 6; Gwin, supra note 45, at 269-70.

319 Gwin, supra note 45, at 269-70.

${ }^{320}$ McGinnis, supra note 2, at 1714.

${ }^{321} I d$. at 1714, 1725 n. 43; Dahl, supra note 2, at 30.

322 See supra note 2 and accompanying text.
} 